\title{
CabApp: Taksi Yolculuğunuzu Doğru Tasarlayın
}

\author{
Yılmaz Kemal Yüce ${ }^{*}$, Ali Çoban², Şerif İnanır ${ }^{3}$, Yalçın İşler ${ }^{4}$ \\ $1^{*}$ Alanya Alaaddin Keykubat Üniversitesi, Rafet Kayış Mühendislik Fakültesi, Bilgisayar Mühendisliği Bölümü, Antalya, Türkiye, (ORCID: 0000-0001-5291-0565), \\ yilmazkemalyuce@gmail.com \\ ${ }^{2}$ Gazi Üniversitesi, Mühendislik Fakültesi, Bilgisayar Mühendisliği Bölümü, Ankara, Türkiye (ORCID: 0000-0002-0372-7737), cobanali978@gmail.com \\ ${ }^{3}$ Yıldız Teknik Üniversitesi, Elektrik-Elektronik Fakültesi, Bilgisayar Mühendisliği Bölümü, İstanbul, Türkiye (ORCID: 0000-0003-3761-3751), \\ sheriffnnr@gmail.com \\ ${ }^{4}$ İzmir Katip Çelebi Üniversitesi, Mühendislik Fakültesi, Biyomedikal Mühendisliği Bölümü, İzmir, Türkiye (ORCID: 0000-0002-2150-4756), islerya@yahoo.com
}

(International Conference on Design, Research and Development (RDCONF) 2021 - 15-18 December 2021)

(DOI: $10.31590 /$ ejosat.1047422)

\begin{abstract}
ATIF/REFERENCE: Yüce, Y. K., Çoban, A., İnanır, Ş. \& İşler, Y. (2021). CabApp: Taksi Yolculuğunuzu Doğru Tasarlayın. Avrupa
\end{abstract} Bilim ve Teknoloji Dergisi, (32), 602-615.

$\ddot{O} \mathbf{z}$

Toplu ulaşım, yolculuk süresi ve ücreti gibi sağladığı avantajlar bakımından sık tercih edilen bir seçenektir. Ayrıca alternatiflerinin aksine daha iyi konfor ve daha düşük Covid-19 bulaşma riski sunar. Diğer taraftan, Türkiye'de taksi yolculuğu için elektronik servislerin yaygınlaşmasıyla birlikte taksi yolculuğu ile ilgili sorunların çeşitliliği ve miktarı artmaktadır. Bu sorunlar dikkate alındığında yolcuların yolculuk sonuçlarının ve yolculuk sonuçlarına ilişkin beklentilerin iki uç noktada sonlanabileceği düşünülebilir. Bu çalışmada, yolcuların yolculuklarını yolculuk öncesinde planlamaları için bir mobil uygulama yazılımı tasarlanmış ve geliştirilmiştir. Uygulama bir dizi dur-kalk konumuyla birlikte (yani başlangıç konumu ve varış noktası arasındaki ara düğümler) alternatif rotaları ve ilgili rotaların yolculuk göstergelerini (ücret, mesafe, süre) hesaplayabilir ve kullanıcıların bunları etkin bir şekilde görüntülemesine olanak tanır. Gerçek yolculuk ücretine çok yakın ve doğru bir tahmin hesaplayabilmek için uygulama, Google'ın Directions API'si tarafından sağlanan verilere dayalı olarak mevcut trafik akışına ve trafik yoğunluğuna bağlı olarak her rota için tahmini bir bekleme süresi hesaplar. $\mathrm{Bu}$ sayede, kullanıcılar toplam yolculuk süresi ve ücreti için gerçek yolculuk değerlerine yakın değerler elde edebilir. Bu çalışma, Jenerik Taksi Yolcuğu Modeli'nin sadece birinci aşamasını uygulayarak yolculuk beklenti ve sonuçlarının uyumsuzluğundan kaynaklı taksi yolculuğu şikayetlerini azaltmayı hedeflemektedir.

Anahtar Kelimeler Akıllı Ulaşım Sistemleri, Yolculuk Planlama, Taksi Şikayetleri, Konuma dayalı hizmetler, taksi.

\footnotetext{
*Sorumlu Yazar: yilmazkemalyuce@gmail.com
} 


\title{
CabApp: Design Your Journey Correctly
}

\begin{abstract}
Public transportation is an option preferred frequently in terms of benefits such as fare and duration of journey. It also offers better comfort and lower risk of contagion, in contrast to alternatives. On the other hand, variety and amount of issues with cab journey is on the rise with widespread use of novel electronic services for taxi journey services in Turkey. Taking these issues into account, it can be considered that expectations of passengers for a journey and journey results might end up on two extremes. In this study, a mobile application software has been designed and implemented for passengers to plan their journeys prior to journey. The application is capable of computing alternative routes with a number of stop-and-go locations (i.e., intermediate nodes between starting location and destination) and related journey indicators (fare, distance, duration) and allows users to display them effectively. To be able to compute a very close and accurate estimate to actual journey fare, the application computes an estimated waiting time for each route depending on data provided by Google's Directions API such as current traffic flow and average journey time on a route. Thereby, users can grasp a close estimate of total journey time and fare of a route. The application implements the first phase of Generic Taxi Journey Model and therefore aims to reduce cab journey issues due to differences between passengers' journey expectations and results of journey.
\end{abstract}

Keywords: Intelligent Transportation Systems, Journey Planning, Taxi Complaints, Location based services, taxi.

\section{Giriş}

Ulaşımın zaman ve maliyet yönünden daha verimli gerçekleştirilebileceği toplu taşıma, etkili ve tercih edilen bir seçenek olarak karşımıza çıkmaktadır. Toplu taşımanın bu yönü, bireylerin ulaşım ihtiyaçlarına karşılık verilmesi ve devamlılığı bakımından günümüz toplumlarında önemli bir konuma sahiptir. Özellikle karayolu ile gerçekleştirilen ulaştırma faaliyetleri, alternatifleriyle (denizyolu, raylı sistemler, vb.) kıyaslandığında daha sık talep edilen bir seçenek olarak yaşantımızda yer edinmiştir. Bu yönü ile karayolu ile toplu ulaşım, sahip olduğu araç sayısı ve özellikle de içerisinde barındırdığı birtakım imkanlar sebebiyle iş ve özel hayatta sıklıkla kullanılan bir alternatiftir [1]. Yerel ölçekte gerçekleştirilen ulaştırma faaliyetleri için sağladığı imkanlar arasında getirdiği hız ve düşük ücretler, yolcular tarafından öncelikli olarak algılanabilecek önemli avantajlardır.

2019 yılında İstanbul'da toplu taşıma hizmetlerinden (karayolu, denizyolu, raylı sistemler, vb.) faydalanan günlük ortalama yolcu sayısı 15.149.333'tür [2]. Ve bu değer, Türkiye'nin en kalabalık şehri ve en karmaşık metropolü olan İstanbul için toplam nüfusun \%97,61'ine karşılık gelmektedir [3]. Kayda geçen yolculuklar incelendiğinde ise 2019 yılında İstanbul için \% 77,1'lik bir oran ile karayolu ulaşımının daha fazla tercih edildiği söylenebilir [2].

Karayolu ulaştırma faaliyetleri için kullanılan birçok yöntem ve araç bulunmaktadır. İlgili yöntem ve araç kategorileri ile ilişkilendirilebilecek örnekler arasına; metrobüs, minibüs, taksi, dolmuş ve benzeri ulaştırma faaliyetleri dahil edilebilir. Bireyin kişisel alanını korumak ve diğer alternatiflere göre daha konforlu bir yolculuğu deneyimlemek istemesi için kullanılan taksi ile ulaşım, 2019 yılı İstanbul istatistikleri dikkate alındığında, ulaşımda önemli bir pay sahibidir. İlgili tarih kapsamında günlük ortalama 1.403.949 yolculuk taksiler vasıtasıyla gerçekleşmiştir. Buna göre; taksi ile yapılan günlük yolculuk sayısı, İstanbul nüfusunun \%9,04'üne, günlük ortalama yolculuk sayısının $\% 9,26$ 'sına ve günlük karayolu ile yapılmış ortalama yolculuk sayısının \%10'una karşılık gelmektedir [2,3].
Elbette taksi ile ulaşımın yoğun olarak tercih edilmesinin beraberinde bazı yolculuk beklentilerinin karşılanmamasından kaynaklanan sorunlar da bulunmaktadır. İstenen sürede ve maliyetle ulaşım beklentisinin elde edilememesi birçok olumsuz çıktının (taksi yolculuğu şikayetleri) sebepleri arasındadır.

2019 yılında İstanbul'da gerçekleştirilmiş taksi yolculuklarıyla ilgili 179.177 şikayet kaydedilmiştir [4]. Şikayetlerin temelinde, yolcuların beklentileri ve gerçekleşen yolculuk sonuçları arasındaki farklılık önemli bir boyuttur. Bu perspektif ile ilişkilendirilebilecek ve daha önce de gerçekleşmiş şikayetlere; şoförlerin yolculuk mesafesini ve dolayısıyla da süresini bilinçli ya da bilinçsiz şekilde uzatmaları, kısa mesafe için ve uygulanan minimum ücretten daha fazlasının talep edilmesi, ücreti tahmini olarak düşünülmüş bir rota için trafik ve yol durumlarının beklenen ücreti ciddi boyutta değiştirmesi örnek olarak verilebilir. Bu sorunların sadece İstanbul bölgesi için geçerli olmadığı görülmektedir. Bu sorunların neler olabileceğine ya da mobil uygulamaların bu sorunlara nasıl etkileri olabileceği Çin'de, Rusya'da ve Suudi Arabistan'da yapılan üç çalışma da incelenmiştir [28,29,36].

Taksi müşterileri, taksilerini aramak ve yönetmek ve hatta en çok tercih ettikleri (favori) taksi şoförüyle ilgili ayrıntıları saklamak için akıllı telefonlarını kullanma eğilimindedir. Ancak çoğu zaman taksi ücretinin nasıl hesaplandığını ve doğru olup olmadığını anlama olanağına sahip değildirler [26-27]. Osswald ve arkadaşları, bu amaca yönelik olarak taksi ücretinin yolculuk sırasında gerçek zamanlı hesaplayan bir mobil uygulama geliştirmişler [26].

Diğer taraftan, ulaşımın sorunsuz şekilde ilerlemesi için yolculuk beklentilerinin yolculuk öncesinde hesaplanması fayda sağlayabilir. Örneğin; A konumundan B konumuna Z rotasından yapılacak bir yolculuğun yaklaşık 30 dakika ve 20 TL tutacağı bir yolculuk öncesi hesaplamayı ele alalım. İlgili yolculuğun 35 dakika ve maliyetin 23 TL tuttuğu bir sonuç, şikayet kapsamında değerlendirilmesi zor bir sonuç olabilir. Fakat diğer taraftan, yolculuk öncesi yapılan tahmin ve yolculuk sonucu arasında ciddi farklar da bulunabilir. İlgili örnekteki rotada yolculuğun 130 dakika ve maliyetin 95 TL tuttuğunu düşünürsek, yolculuğun ciddi şekilde sorunlu geçtiği söylenebilir. 
Literatürde taksi hizmeti üzerine geliştirilmiş mobil uygulamalarda yolculuk 5 (beş) aşamalı modellendirilmiştir. $\mathrm{Bu}$ aşamalar Yolculuk Tasarlama (1), Yolculuk Eşleştirme (2), Taksi bekleme (3), Yolculuk Seyir Takibi (4), ve Yolculuk Sonu ve Sonrası (5) olarak isimlendirilmiştir [5]. Yolculuk öncesi hesaplamaların (ve tahminlerin) yapılması Yolculuk Tasarlama aşamasında gerçekleşmektedir [5]. Yolculuk Tasarlama aşaması, yolculuk ile ilgili bazı sorulara yolculuk öncesinde cevap arayarak, yolculuk seyrinin yönetilmesini sağlayabilir. Genel olarak, bu sorular aşağıda belirtildiği gibi;

- Alternatif güzergahlardan hangisinin tercih edileceğine ve mesafe bilgisine,

- Yolculuğun ne kadar süre ve maliyet tutacağına yöneliktir.

Literatürdeki Yolculuk Tasarlama aşamasını içeren veya buna dayalı çalışan uygulamalar incelendiğinde. Tablo 1'de görülen uygulamalar Google Play Store'da yabancı uygulamalar için $\{$ "Taxi Fare"\}, \{"Taxi Calculator "\} ve yerli uygulamalar için
\{“Taksi fiyat hesaplama"\}, \{“Taksimetre fiyat hesaplama "\} anahtar kelimeleri ile arama yapılmış ve bu aramalar sonucu 1. aşama kapsamında çalıştıklarından bu çalışma kapsamında incelenmek için seçilmiştir [6-7].

İşlevleri itibariyle bu uygulamalar incelendiğinde;

- Başlangıç ve Bitiş Adreslerine Göre Yolculuk Rotası Hesaplamak ve Haritada Göstermek

- $\quad$ Rota İçin Toplam Yolculuk Mesafesini Hesaplamak

- Rota için Tahmini Toplam Yolculuk Süresi Hesaplamak

- Rota için Tahmini Toplam Yolculuk Ücreti Hesaplamak (Taksimetre ölçümüne dayalı tahmini ücretlendirme)

işlevlerinin genellikle uygulamaların çoğunda görüldüğü tespit edilmiştir. $\mathrm{Bu}$ işlevler birinci aşamada yer alabilecek en temel işlevlerdendir. Ayrıca Taxi-Calculator ve Thai Taxi Calculator uygulamalarında 5. aşamada görülen favori adres ekleme işlevide bulunmaktadir [5, 8-12].

Tablo 1. Uygulamalar ve İncelenen Özellikler

\begin{tabular}{|c|c|c|c|c|c|c|}
\hline & & $\begin{array}{c}\text { Taxi } \\
\text { Calculator }\end{array}$ & $\begin{array}{l}\text { Thai Taxi } \\
\text { Calculator }\end{array}$ & $\begin{array}{l}\text { Taxi Fare } \\
\text { Calculator }\end{array}$ & $\begin{array}{l}\text { istTaksi- } \\
\text { Taksimetre }\end{array}$ & $\begin{array}{l}\text { Taxi } \\
\text { Fare }\end{array}$ \\
\hline \multirow{14}{*}{$\begin{array}{l}\text { Yolculuk } \\
\text { Öncesi } \\
\text { Yolculuk } \\
\text { Tasarımı } \\
\text { (Yolculuk } \\
\text { Hakkında Ön } \\
\text { Bilgilendirmeye } \\
\text { Dayalı Model) }\end{array}$} & $\begin{array}{l}\text { Başlanngıç ve Bitiş Rotasına Göre Yolculuk } \\
\text { Rotası Hesaplamak ve Haritada Göstermek }\end{array}$ & $\checkmark$ & $\checkmark$ & $\checkmark$ & $\checkmark$ & $\checkmark$ \\
\hline & $\begin{array}{c}\text { Başlangıç ve Bitiş Adreslerine Göre } \\
\text { Alternatif Yolculuk Rotalarını Hesaplamak } \\
\underline{\text { ve Haritada Göstermek }}\end{array}$ & $\mathbf{x}$ & $\mathbf{x}$ & $\mathbf{x}$ & $\mathbf{x}$ & $\mathbf{x}$ \\
\hline & Duraklı Rota Hesaplayabilmek & $\mathbf{X}$ & $\mathbf{x}$ & $\mathbf{x}$ & $\mathbf{x}$ & $\mathbf{X}$ \\
\hline & $\begin{array}{l}\text { Geçmiş Yolculuklarındaki Rotaları ya da } \\
\text { Favori Rotaları Görüntülemek }\end{array}$ & $\mathbf{x}$ & $\mathbf{x}$ & $\mathbf{x}$ & $\mathbf{x}$ & $\mathbf{x}$ \\
\hline & $\begin{array}{l}\text { Rotadaki Genel Trafik Durumunu Haritada } \\
\text { Göstermek (Rota Üzerindeki Trafik Akış ve } \\
\text { Sıkışıklkklarını Göstermek) }\end{array}$ & $\mathbf{x}$ & $\mathbf{x}$ & $\mathbf{x}$ & $\mathbf{x}$ & $\mathbf{x}$ \\
\hline & $\begin{array}{c}\text { Rota İçin Toplam Yolculuk Mesafesini } \\
\text { Hesaplamak }\end{array}$ & $\checkmark$ & $\checkmark$ & $\checkmark$ & $\checkmark$ & $\checkmark$ \\
\hline & 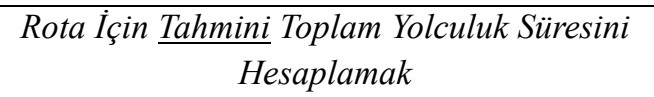 & $\checkmark$ & $\checkmark$ & $\checkmark$ & $\checkmark$ & $\checkmark$ \\
\hline & $\begin{array}{c}\text { Rota İçin Tahmini Toplam Yolculuk Ücreti } \\
\text { Hesaplamak (Taksimetre Ölçümüne Dayalı } \\
\text { Tahmini Ücretlendirme) }\end{array}$ & $\checkmark$ & $\checkmark$ & $\checkmark$ & $\checkmark$ & $\checkmark$ \\
\hline & $\begin{array}{c}\text { Rota İçin Uygulanacak Nihai Ücreti Yolculuk } \\
\text { Öncesinde Hesaplamak (Dinamik } \\
\text { Ücretlendirme) }\end{array}$ & $\mathbf{x}$ & $\mathbf{x}$ & $\mathbf{x}$ & $\mathbf{x}$ & $\mathbf{x}$ \\
\hline & Taksi Tipi Seçmek (Sarı, Turkuaz, Siyah) & $\mathbf{x}$ & $\mathbf{x}$ & $\mathbf{x}$ & $\mathbf{x}$ & $\mathbf{x}$ \\
\hline & $\begin{array}{c}\text { Yolculuğun Tahmini Bitiş Süresini ve } \\
\text { Gecikmeler Halinde Oluşabilecek Son Bitiş } \\
\text { Süresini Göstermek }\end{array}$ & $\mathbf{x}$ & $\mathbf{x}$ & $\mathbf{x}$ & $\mathbf{x}$ & $x$ \\
\hline & $\begin{array}{c}\text { İleri Bir Zaman Dilimi İçin Yolculuk } \\
\text { Planlamak }\end{array}$ & $\mathbf{x}$ & $\mathbf{x}$ & $\mathbf{x}$ & $\mathbf{x}$ & $\mathbf{x}$ \\
\hline & $\begin{array}{c}\text { Tercih Edeceği ya da Favori Soför ile } \\
\text { Yolculuk Imkanı Sunmak }\end{array}$ & $\mathbf{x}$ & $\mathbf{x}$ & $\mathbf{x}$ & $\mathbf{x}$ & $\mathbf{x}$ \\
\hline & Favori rotaları görüntüleme (gösterme) & $\mathbf{x}$ & $\mathbf{x}$ & $\mathbf{x}$ & $\mathbf{x}$ & $\mathbf{x}$ \\
\hline
\end{tabular}


$\mathrm{Bu}$ işlevlerin dışında kalan işlevlere bakıldığında Rotadaki Genel Trafik Durumunu Haritada Göstermek (Rota Üzerindeki Trafik Akış ve Sıkışıklıklarını Göstermek), Taksi Tipi Seçmek (Sarı, Turkuaz, Siyah), İleri Bir Zaman Dilimi İçin Yolculuk Planlamak, Tercih edeceği ya da favori şoför ile yolculuk imkanı sunmak işlevlerinin tüm aşamaları kapsayan uygulamalarda daha ön plana çıktığı görülmektedir [5]. Geriye kalan işlevlerin ise uygulamalar bazında farklılıklar gösterdiği görülmektedir.

$\mathrm{Bu}$ çalışmanın amacı; Yolculuk Tasarlama aşamasını, yolcunun hakimiyetini arttırmaya yönelik olarak yolculuk göstergelerini yolculuk sonunda alacakları değerlere en yakın şekilde hesaplayan bir çözüm modellemek ve ilgili modeli bir mobil uygulama yazılımı olarak gerçekleştirmektir. Bu yapının oluşturulması için başlangıç ve varış konumu (ve varsa ara durak konumları), yolculuk saati ve taksi tipi bilgileri modele girdi olarak verilir. Basitçe, alınan girdiler kullanılarak model tarafından yolculuk rotaları hesaplanır. Her bir rota için toplam yolculuk mesafesi, tahmini yolculuk süresi ve tahmini yolculuk ücreti hesaplanarak kullanıcıya sunulur. Ayrıca yolcunun yolculuk rotasına karar vermesinde yardımcı olabilecek bir işlev daha eklenmiştir: Yolcunun yolculuk etmek isteyeceği rotanın karakteristik özelliğine göre (en ucuzu, en az yolculuk süresine sahip olanı, en kısa mesafeli ve en az trafiğe sahip olanı), tanımlanan rotaları önerilen ve alternatif rotalar olarak kategorilere ayırmak.

Çalışmanın yukarıda bahsedilen yönleri, yolculuk sonuçlarının önceden tahmin edilebilmesini ve yolculuk beklentilerinin gerçek değerlere yakınsamasını amaçlar. Böylece taksi yolculuğu ile ilgili şikayetleri yolculuk başlamadan önce azaltmayı hedefler.

Bunlara ek olarak, yolculuk ücretinin daha yüksek doğrulukla hesaplanabilmesi için yeni bir bekleme süresi hesaplama yaklaşımı modellenmiştir. Bekleme süresi, ücret hesaplaması için gereklidir ve taksinin yolculuk boyunca hareketsiz kalacağı süreyi ifade eder. Bekleme süresinin ücret hesaplamasındaki beklenen faydasının yanısıra, bir rotadaki trafik yoğunluğu hakkında fikir verebileceği de söylenebilir. İlgili model, bekleme süresini bazı istatistiksel yöntemler ve kabuller doğrultusunda tahmin etmeye çalışır.

Çalışmanın bir sonraki bölümü olan Materyal ve Metot'ta, ilgili aşama kapsamında oluşturulan sistemin mimarisi, işlevleri ve hesaplamaya yönelik algoritmaları açıklanmaktadır. Çalışmanın diğer bir bölümü olan Sonuç ve Tartışma ise, çalışmanın genel yapısına ve ilgili yapı üzerindeki çıkarımlara yer vermektedir.

\section{Materyal ve Metot}

\subsection{Ana Kullanım Senaryosu}

Yolculuk öncesi planlamaya dayalı modelimiz, istenilen konumlar için güzergahları (rota olarak da isimlendirilir) ve güzergahlar için bazı yolculuk değişkenlerini hesaplar. Model dinamiklerinin gerçekleştirilmesi aşamasında ise bir mobil uygulama yazılımı tasarlanmış ve geliştirilmişstir.

Modelin rota hesaplayabilmesi için iki veriye ihtiyacı vardır: başlangıç ve varış konumu. İlgili değerlerin girdi olarak alınabilmesi için uygulamanın kullanıcı arayüzünde bir harita bileşeni mevcuttur. Harita bileşeni kullanıcıların anlık, başlangıç e-ISSN: 2148-2683 ve varış konumlarını işaretleyerek gösterimini sağlar. Ayrıca alınan girdilerle hesaplanacak rotalar da harita üzerinde sunulur. Bu anlamda harita, verilerin görselleştirilmesi işlevini güder.

İsteğe bağlı olarak modele dahil edilebilecek diğer bir değişken ise durak konumlarıdır. Duraklar, başlangıç konumundan varış konumuna kadar sıralı olarak gidilmesi planlanmış ara noktalardır. Durakların tanımlanmasıyla birtakım faydalar elde edilebilir. Bu faydalardan ilki, her durak konumu için ayrı rota hesaplama ihtiyacının kalkmasıdır. Bu sayede, kullanıcının sıralı olarak A, B ve C konumlarına gidebilmesi için; A'dan B'ye ve B'den C'ye ayrı rotalar hesaplanmaz ve görüntülenmez. Bu örnek üzerine, sistemin hesaplayacağı tek rota A'dan C'ye doğrudur. Durak belirlemenin diğer bir faydası ise, hesaplanacak rotaya yolcunun müdahale edebilmesidir. Böylece rotaların hesaplanmasında yolcu kendi sezgiselliğini kullanabilir ve hesaplanan rotalara dahil edilecek otoban, köprü ve benzeri güzergah bileşenlerini seçebilir.

Hesaplanan rotaların kullanıcıya sunumu iki kategoride gerçekleşir: önerilen ve alternatif rota. Önerilen rotanın seçilmesinde, yolcunun tercih etmek isteyeceği rota kriteri bilgisinin arayüz üzerinden belirlenmesi gerekmektedir. Rota kriterleri dört adet olmak üzere Hızlı, Kısa, Ucuz ve Rahat'tır. Hızlı, tahmini yolculuk süresinin en az olduğunu; Kısa, gidilecek rota mesafesinin en az olduğunu; Ucuz, tahmini yolculuk ücretinin en az olduğunu; Rahat ise ilgili bir rotadaki bekleme süresinin (diğer bir ifadeyle trafiğin) en az olduğunu ifade etmektedir. $\mathrm{Bu}$ kategorilendirme ardından, seçilen kriter baz alınarak önerilen rota belirlenir. Diğer tüm rotalar ise alternatif rota olarak isimlendirilir.

Ayrıca her bir rota için tahmini yolculuk ücreti de hesaplanarak kullanıcı arayüzünde sunulmaktadır. Uygulama tahmini yolculuk ücretini hesaplayabilmek için rotanın toplam mesafesi yanında üç yolculuk değişkenine daha ihtiyaç duyar. Bunlardan ikisi, yolcudan alınacak olan taksi tipi ve yolculuğun gerçekleşeceği tarih/saattir. Genel olarak Türkiye'de üç taksi tipi mevcuttur ve bunlar sarı, turkuaz ve siyah taksi olarak isimlendirilmiştir. Modelin taksi tiplerine göre çalışma zorunluluğunun sebebi, farklı taksi tipleri için farklı ücretlendirmelerin kullanılmasıdır. Benzer şekilde, farklı saat dilimleri için de farklı ücretlendirme politikaları uygulanabilir. Örneğin Gündüz ve Gece Tarifesi, yolculuk ücretini farklı kat sayılarla artırır. Üçüncü ve sistem tarafindan hesaplanacak değişken olan bekleme süresi ise; yolculuk boyunca taksinin hareket etmediği zaman dilimlerinin toplamıdır.

Uygulama üzerinden ayrıca trafik yoğunlukları da görüntülenebilir. Bu konuda Google haritalar, rotaların o anki yoğunluk düzeyini belirtmek için farklı renkler kullanır. $\mathrm{Bu}$ renkler sarı, kırmızı ve yeşil olmak üzere 3 adettir. Kırmızı renk rotadaki trafik durumunun çok yoğun olduğunu belirtir. Sarı renk trafik yoğunluğunun orta düzeyde olduğunu gösterir. Sar1 rengin tonu turuncuya doğru değiştikçe rotadaki trafik yoğunluğu artmaktadır. Yeşil renk ise rota üzerinde trafik yoğunluğunun çok düşük seviyede olduğunu gösterir. Genel olarak, bir rengin koyulaşması trafik yoğunluğunun arttığını, açıklaşması ise azaldığını göstermektedir.

Google trafik tahminlerinin doğruluğunu arttırmak için 2009 yılından itibaren android cihazlardan yararlanmaya başladı. Android telefon kullanıcıları GPS (Global Positioning System; Küresel Konumlama Sistemi) konumları etkinken Google Haritalar uygulamalarını açtığında Android telefonlar Google'a 
anonim veriler gönderir. Google topladığı bu veriler sayesinde araçların yollarda ne kadar hızlı hareket ettiğini hesaplar. Google Haritalar yollardaki tüm arabalardan gelen verileri sürekli olarak birleştirir. Elde edilen veriler ve hesaplanan bilgiler sonucunda

Google Haritalarda trafik yoğunluklarını gösteren kırmızı, sarı ve yeşil renkli rota parçaları oluşturulur [14-22].

\subsection{Sistem Mimarisi}

Şekil 1 CapApp Uygulaması Sistem Mimarisi, tasarlanan sistemin bileşenleri ve aralarındaki ilişsiyi göstermektedir: Kırmızı renkli ok kullanıcı etkileşimini; sarı renkli oklar yerel sistem etkileşimlerini, yeşil renkli oklar ise uzak etkileşim olan API etkileşimini ifade etmektedir. Buna göre sistemin tek aktörü olan yolcu, bir mobil cihaz üzerinde çalıştırılan uygulama yazılımını kullanarak kendisi için tanımlanmış görevleri gerçekleştirebilir.

Aşağıda, ilgili şekilde gösterimi yapılmış bileşenler hakkında mimari detaylara yer verilmiştir:

-CabApp uygulaması, aktör görevlerinin gerçekleştirilmesi için kullanılacak olan tek bileşendir. Temel olarak uygulama üzerinden başlangıç ve varış konum bilgileri girilerek rota ve ilgili rotanın tahmini yolculuk göstergelerine erişilebilir. Uygulamanın geliştirilme aşamasında çapraz platform (cross-platform) uygulama geliştirmeye yarayan Google tarafindan geliştirilen Flutter çatısı (framework) (version 2.2.2) kullanılmıştır. Flutterda kullanılan Dart programlama dilinin 2.13.3 sürümü kullanılmıştır.

- Yerel veritabanı mobil cihazda depolanır. Geliştirilen uygulamada SQLite (version 3.35.5) veritabanı yönetim sistemi kullanılmıştır. Genel olarak, rota hesaplamalarının yapılabilmesi için taksimetre hesaplama katsayıları ve değişkenlerini barındırır. Bu veritabanında tarife bilgilerinin doğru bir biçimde alınabilmesi için şehir bilgileri, ülke bilgisi, özel bölge bilgileri ve bu yerlere ait içinde belirli değişkenleri barındıran tarife bilgileri bulunmaktadır [35].

- Google API'leri rota hesaplanması ve görselleştirilmesi için kullanılır [30-34]. Google Maps API (GMA) kullanıcı arayüzünde harita bileşenini yaratır. Google Geocoding API (GGA), GMA ile ortaklaşa çalışır ve konumların harita bileşeninde gösterilmesini sağlar. Google Directions API (GDA) ise rota hesaplaması için kullanılmaktadır. Google Places API (GPA) rota hesaplamasında GDA'da kullanılan konum bilgilerini almak için kullanılmaktadır. Son olarak Google Places Autocomplete API (GPAA) kullanıcıya bir adres ararken öneri sunmak ve Google Places API'ye place id bilgisini iletmek için kullanılır.

GDA'nın kullanılabilmesi için konum girdilerine ihtiyaç vardır. Konum girdileri bir liste yapısında tutulur. Listenin ilk elemanı başlangıç konumuna ve son elemanı varış konumuna karşılık gelmektedir. Dolayısıyla en az iki konum girdisiyle GDA kullanılabilir. Eğer var ise, girdi olarak alınma sıralarına göre ara durak konumları da konum listesine eklenir. Böylece ikiden fazla konum girdisi için tek rota oluşturulabilir. Fakat GDA'nın getirmiş olduğu konum kısıtlaması sebebiyle, konum listesinin alabileceği eleman sayısı en fazla 25 olarak tanımlanmalıdır. Buna göre; bir başlangıç, en fazla 23 ara durak ve bir varış konum girdisiyle rota hesaplanabilir.

Rotaların hesaplanması için konum listesi GDA'nın Web servisine gönderilir. İlgili servis, aldığı konum listesini kullanarak rotaları hesaplar. Hesaplama sonuçları JSON formatındaki bir cevap mesajıyla geri gönderilir. Cevap mesajında genellikle birden fazla rota hesaplaması bulunur. Her bir rota hesaplamas 6 anahtar alan barındırır: başlangıç konumu, varış konumu, sıralı olarak gidilecek yol parçalarının bilgileri, rotadaki anlık trafiğe ve geçmiş yolculuk bilgilerine bağlı yolculuk süresi, rotadaki ortalama yolculuk süresi, toplam mesafe.

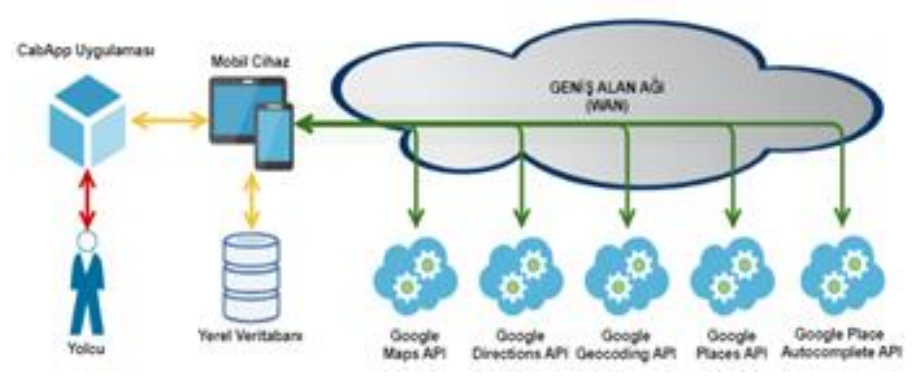

Şekil 1 CabApp Uygulamast Sistem Mimarisi

\subsection{Yapısal Analiz ve Tasarım Tekniği}

Yapısal Analiz ve Tasarım Tekniği (Structured Analysis and Design Technique- SADT) bir sisteme ait görevlerin hiyerarşik olarak modellendiği bir mimari tasarım metodolojisidir [23]. Geliştirilen uygulamanın modellenmesinde de SADT kullanılmıştır. Tasarlanan SADT aktiviteleri bu bölüm altında gösterilmekte ve açıklanmaktadır.

Çalışmanın en temel işlemlerini ve aralarındaki ilişkiyi gösteren ana sistem aktivitesi, Şekil 2'de verilmektedir. Bu aktivite altında sırasıyla; sistemi ilklendirme, yolculuk rotalarının görüntülenme, yolculuk göstergeleri hesaplama ve önerilen rotayı gösterme işlevlerini barındıran alt aktiviteler yer almaktadır. Bahsi geçen diğer tüm aktiviteler, Şekil 2'de gösterimi yapılan ana aktivite kapsamında ele alınacak olup, aşağıda açıklamaları yapılmaktadır.

Şekil 3'te "İlklendirme ve Hazırlık İşlemlerini Gerçekleştirme" aktivitesi bulunmaktadır. İlgili aktivitede, uygulama kendini kullanılabilir duruma getirmek için Api ve veritabanı bağlantılarını gerçekleştirme gibi temel işlevleri yerine getirir. Buna göre; Veritabanı, GPA, GGA, GDA, GPAA GAA ve GMA bağlantıları ve verilerin görselleştirileceği harita bileşeni yaratilir.

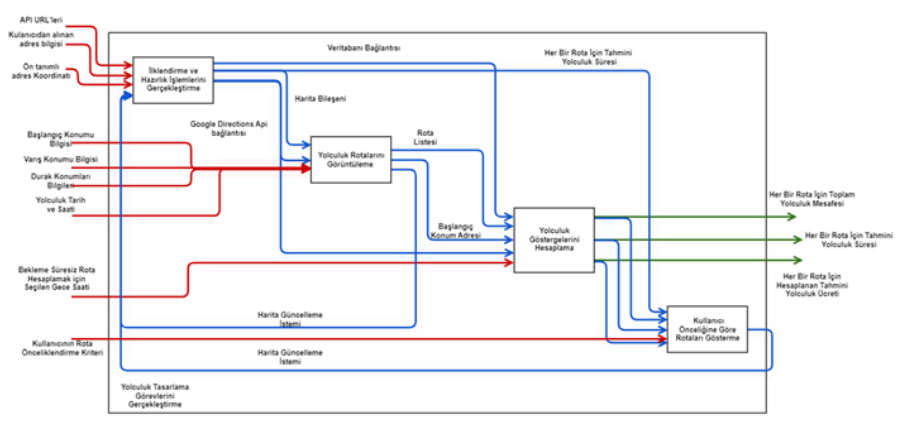

Şekil 2 Yolculuk Tasarlama Görevlerini Değiștirme 


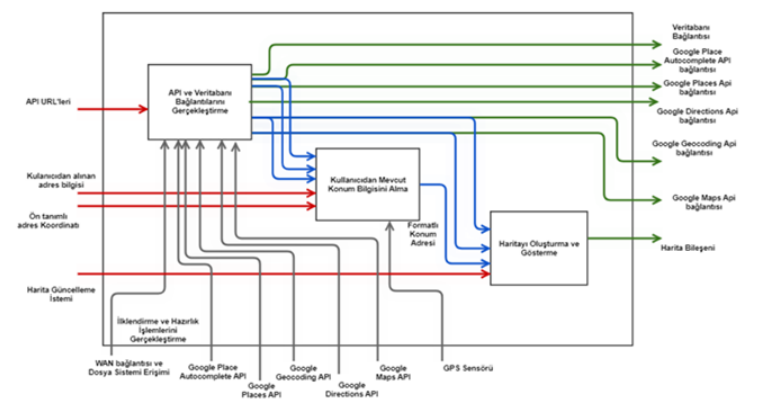

\section{Şekil 3 İlklendirme ve Hazırlık İşlemlerini Gerçekleştirme}

Şekil 4'te "Kullanıcıdan Mevcut Konum Bilgisini Alma" aktivitesi bulunmaktadır. İlgili aktivite, uygulama ilklendirilirken kullanılacak mevcut konum adresini belirler. Mevcut konum adresini belirlemek için iki yöntem tanımlanmıştır. Birincisinde, uygulama tarafindan Küresel Konumlama Sistemi (Global Positioning System- GPS) kullanılarak, mevcut konum doğrudan alınır. İkincisinde, GPS'in olmadığı veya kullanılmak istenmediği durumlar için, kullanıcıdan alınacak geçerli bir adres girdisine ihtiyaç vardır.

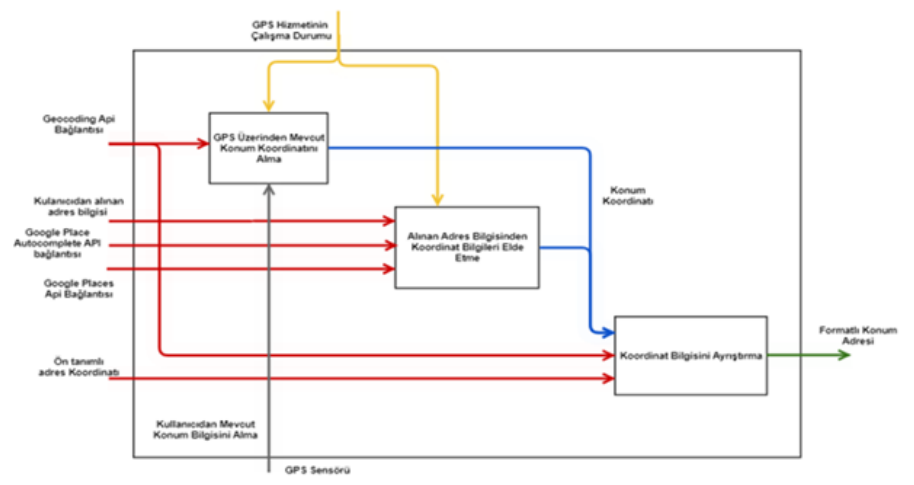

Şekil 4 Kullanicıdan Mevcut Konum Bilgisini Alma

Şekil 5'te "Haritayı Oluşturma ve Gösterme" aktivitesi bulunmaktadır İlgili aktivite, verilerin görselleştireleceği harita bileşenini yaratır ve mevcut konumu gösterecek şekilde harita bileşeninin koordinatlarını düzenler. Buna göre yaratılan "Harita Bileşeni" çıktı olarak verilir. Ayrıca "Harita Bileşenini Güncelleme" isimli alt aktivitede, kullanıcıya sunulmak istenen verilerle harita bileşeni güncellenir. $\mathrm{Bu}$ modele göre; harita bileşenini sadece bir aktivitede güncellemenin arkasındaki tasarım nedeni, harita bileşenini kullanan farklı süreçlerin aynı (en son düzenlemiş) bileşene erişebilmesini sağlamaktır.

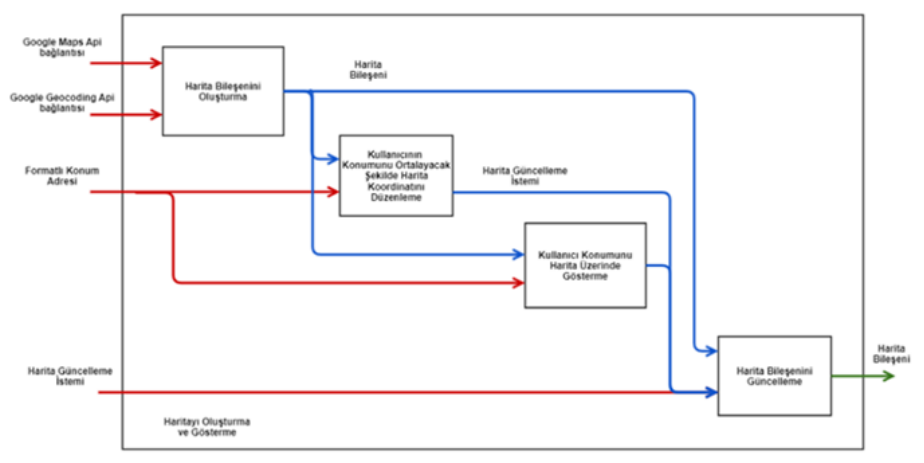

Şekil 5 Haritayı Oluşturma ve Gösterme
Şekil 6'da "Yolculuk Rotalarını Gösterme" aktivitesi bulunmaktadır. İlgili aktivite, kullanıcıdan alınan konum bilgileri ve yolculuk tarih/saat değerini kullanarak rotaları hesaplar. Hesaplanan rotalar bir liste formatında çıktı olarak verilir. Ayrıca, rotaların harita üzerinde sunulması için "Harita Bileşenin Güncelleme" aktivitesine bir güncelleme isteği gönderir.

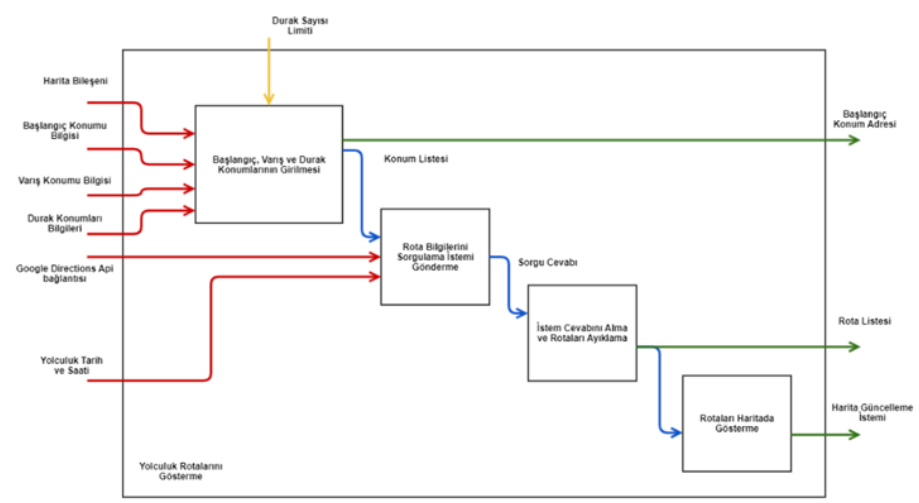

Şekil 6 Yolculuk Rotalarını Gösterme

Şekil 7'de "Başlangıç, Varış ve Durak Konumlarının Girilmesi" aktivitesi bulunmaktadır. İlgili aktivite, rotaların hesaplanması için gereken konum bilgilerini (başlangıç, varış ve varsa durak) kullanıcının girmesini sağlar ve bunları kullanarak bir liste oluşturur. Ayrıca, alınan konum bilgilerinin harita üzerinde sunulması (örneğin; varış konumunun kırmızı bir daire içerisine alınması) için "Harita Bileşenini Güncelleme" aktivitesine bir güncelleme isteği gönderir.

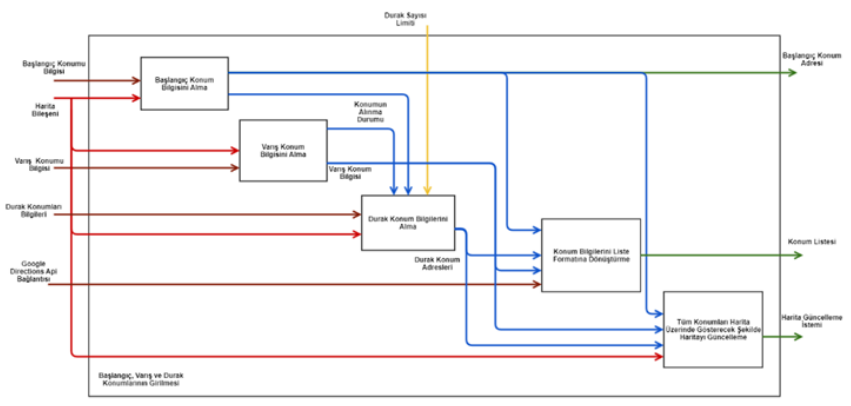

Şekil 7 Başlangıç, Varış ve Durak Konumlarının Girilmesi

Şekil 8'de "Yolculuk Göstergelerini Hesaplama" aktivitesi bulunmaktadır. İlgili aktivite, her bir rotanın tahmini yolculuk ücretini hesaplar ve çıktı olarak verir. Ayrıca, rotalarla birlikte hesaplanan yolculuk süresi ve yolculuk mesafesi de çıktı olarak verilir.

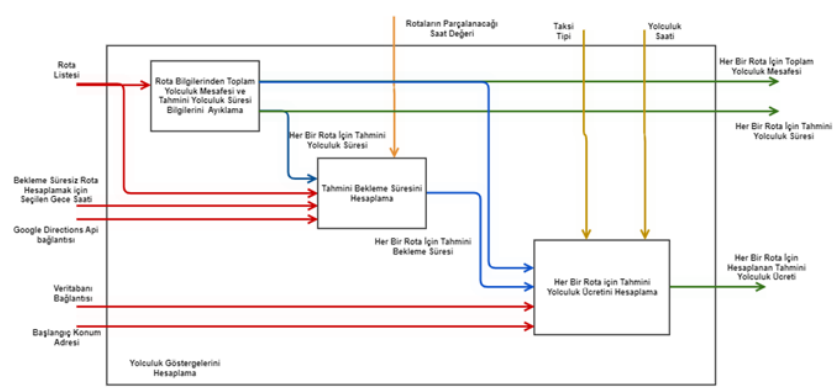

Şekil 8 Yolculuk Göstergelerini Hesaplama 
Şekil 9'de "Tahmini Bekleme Süresini Hesaplama" aktivitesi bulunmaktadır. İlgili aktivite, her bir rotanın yolculuk süresindeki, tahmini toplam bekleme süresini hesaplar. $\mathrm{Bu}$ aktivitenin hesaplama yaklaşımı, "2.6.1 Tahmini Bekleme Süresi hesaplama” bölümü altında açıklanmaktadır.

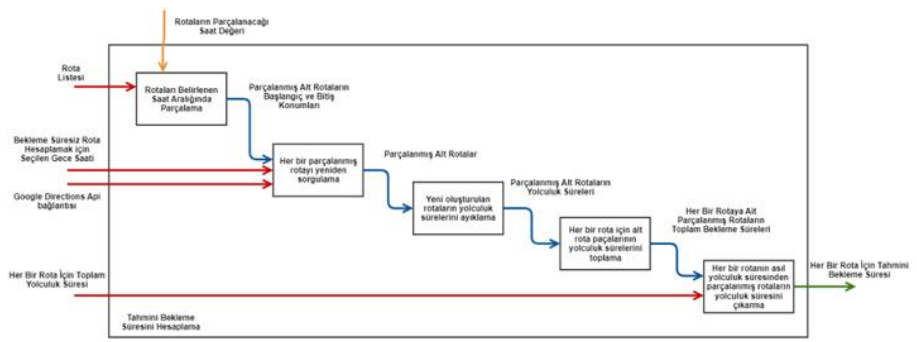

Şekil 9 Tahmini Bekleme Süresini Hesaplama

Şekil 10 ve Şekil 11'de, "Her Bir Rota için Tahmini Yolculuk Ücretini Hesaplama" ve "Bekleme Süresi ve Mesafe Bilgisine Dayalı Olarak Tahmini Ücretlendirmeyi Hesapla" aktiviteleri bulunmaktadır. İlgili aktiviteler, her bir rota için tahmini yolculuk ücretini hesaplar ve çıktı olarak verir. Bu aktivitelerin hesaplama yaklaşımı, "2.6.2 Her Bir Rota İçin Tahmini Ücret Hesaplama" bölümü altında açıklanmaktadır.

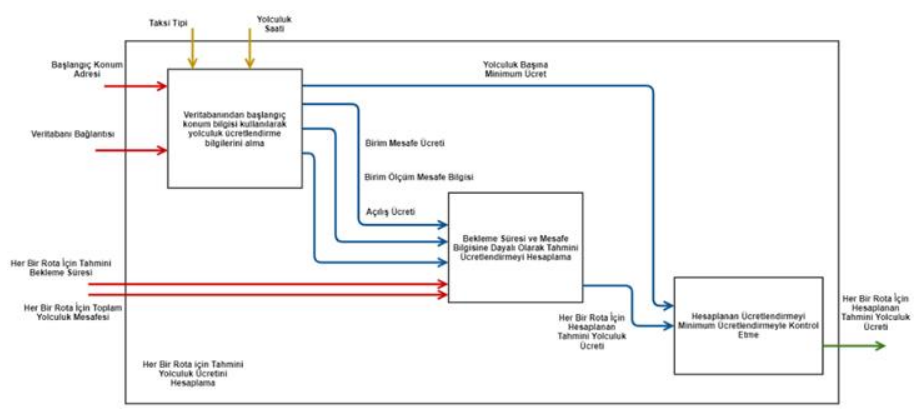

Şekil 10 Her Bir Rota için Tahmini Yolculuk Ücretini Hesaplama

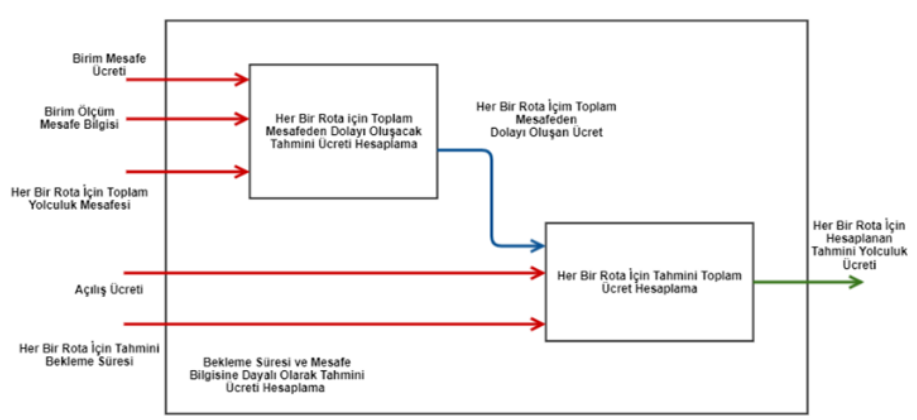

Şekil 11 Bekleme Süresi ve Mesafe Bilgisine Dayalı Olarak
Tahmini Ücreti Hesaplama

Şekil 12'de "Kullanıcı Önceliğine Göre Rotaları Gösterme" aktivitesi bulunmaktadır. İlgili aktivite, yolcunun öncelikli rota tercihini alır ve hesaplanan rotalar arasından bir rotayı "Önerilen Rota" olarak işaretler. Önerilmiş rotanın diğer rotalardan farklı renkte sunulması için harita güncelleme istemi oluşturulur.

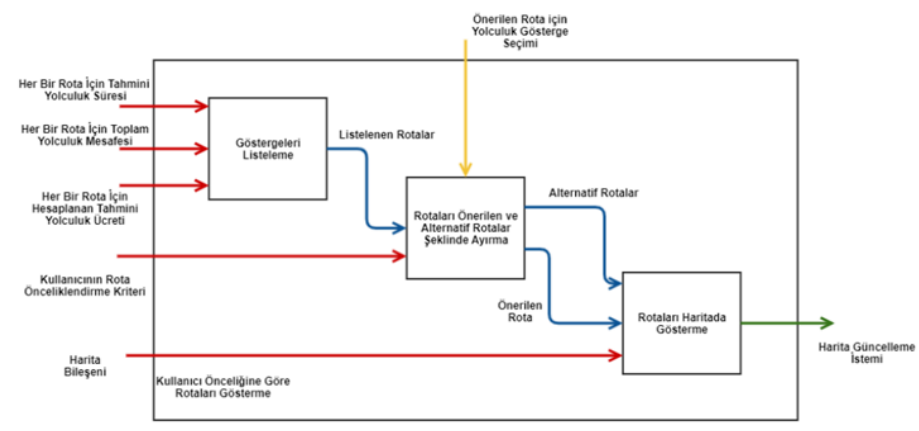

Şekil 12 Kullanıcı Önceliğine Göre Rotaları Gösterme

\subsection{Veri Modeli}

Şekil 13'teki Veri modeli, Varlık-İlişki Yaklaşımı benimsenerek tasarlanmıştır. Modelde, 11 varlık ve 10 ilişsi bulunmaktadır.

Veri modelinin tasarımında 2 farklı renkte ok şekli kullanılmıştır. Kırmızı renkli oklarla ücret hesaplanmasında, mavi renkli oklarla ise yolculuk göstergelerinin kayıt altına alınmasında kullanılan varlıklar ve bunların ilişkileri gösterilmektedir.

Şekilde görülen Taksi Tipi-Tarife varlığına bağlı olan Bölge, Şehir, Ülke varlıklarında veritabanından bulunan bölgeye özel tarifeyi alabilmek için bilgiler bulunmaktadır. Bir ülkede birden fazla şehir ve bir şehirde birden fazla bölge bulunabileceğinden dolayı bu varlıklar arasında 1-M (bire- çok) ilişki bulunmaktadır. Fakat bir bölge ya da şehirde sadece bir tarife olabileceğinden Bölge varlığı ve Taksi Tipi-Tarife varlığı arasında 1-1 (bire-bir) ilişki bulunmaktadır. Aynı şekilde Taksi Tipi- Tarife varlığına bağlı olan Tarife Zamanı zaman ile alakalı bilgileri (gece-gündüz tarifesi), Taksi Tipi varlığıda Taksiye ait bilgileri (Sarı, Siyah renk vb.) tutmaktadır. Bu iki varlık Taksi Tipi- Tarife varlığıyla 1-M ilişki içerisindedir. Taksi Tipi- Tarife varlığı diğer bir değişken olan Tarife Tipi varlığıyla (tarife değişkenlerinin bulunduğu varlık) 1-M ilişki içerisindedir.

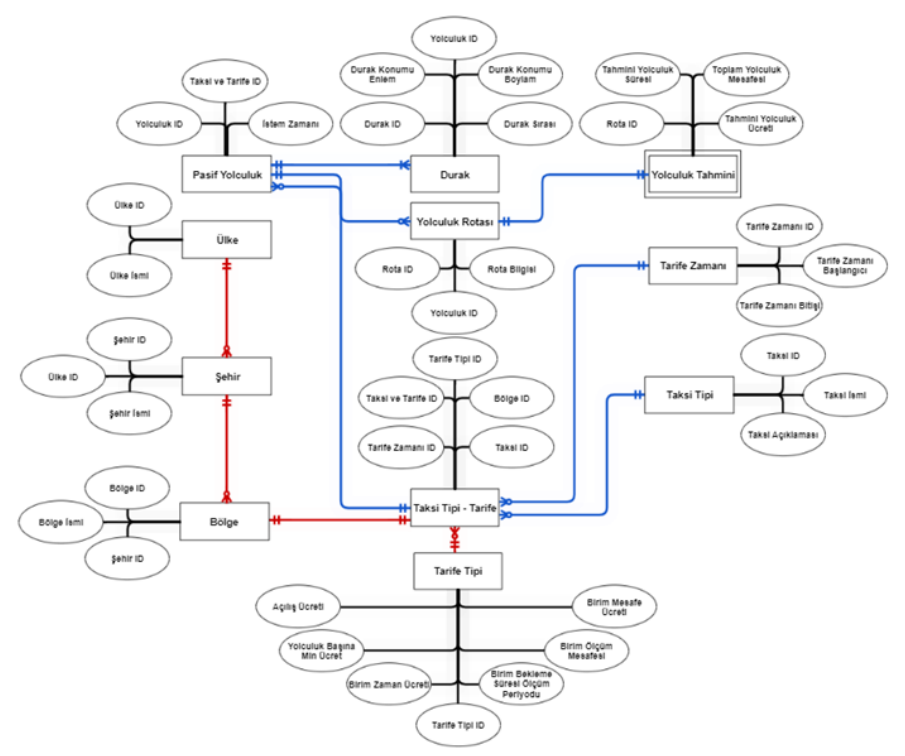

Şekil 13 Veri Modeli 
Pasif yolculuk varlığg 3 varlık ile ilişki kurmaktadır. Bunlar yolculuğun tasarlanmasında kullanılan konum bilgilerini tutmak için Durak varlığı, rota bilgilerini tutmak için Yolculuk Rotası varlığ1 ve son olarak ücret bilgisini hesaplamak için gerekli olan bilgilerin tutulduğu Taksi-Tarife varlığıdır. Bir tarife için birden fazla pasif yolculuk olabileceğinden pasif yolculuk ile TaksiTarife arasında 1-M ilişki bulunmaktadır. Bir pasif yolculukta yine birden fazla durak olabileceğinden Durak ve Pasif yolculuk arasında 1-M bir ilişki bulunmaktadır. Son olarak bir pasif yolculukta birden fazla rota olabileceği için Pasif Yolculuk ve Yolculuk Rotası arasında 1-M bir ilişki bulunmaktadır.

Yolculuk değişkenlerinin bulunduğu Yolculuk Tahmini isimli zayıf varlık, sahip olduğu niteliklerden dolayı Yolculuk Rotası ile 1-1 ilişki içerisindedir. Bunun nedeni bir rotanın bilgisinde sadece birer tane tahmini yolculuk süresi, tahmini yolculuk mesafesi ve tahmini yolculuk ücreti içermesidir.

\subsection{Kullanıcı Arayüz Tasarımı}

Sistem aktörünün tüm görevlerini gerçekleştirmesi ve takip edebilmesi için kullanılacak tek araç, bir mobil uygulama yazılımı olarak tasarlanmış ve gerçekleştirilmiştir. İlgili yapıda kullanılan arayüz bileşenlerini ve aralarındaki ilişkiyi gösteren durum diyagramı Şekil 14'te gösterilmektedir. Şekilde durumlar üç farklı renk tonuyla gruplanmaktadır. Kırmızı tonlardaki durumlar, ebeveyn durumun sahip olduğu tüm arayüz alanını kullanırlar. Yeşil durumlar, ebeveyn durumun sahip olduğu arayüz alanının belirli bir parçasını kullanırlar. Mavi durumlar ise, belirli bir alanda üst üste konumlandırılarak (bir yığın oluşturularak), ebeveyn durumun sahip olduğu tüm arayüz alanını veya bunun bir parçasını kullanabilirler. Ek olarak, durumlar arası ilişkiyi ifade eden oklar ise iki gruba ayrılmaktadır. Renkli oklar, girdi ve çıktı ok renklerinin aynı olması gerektiğini; siyah renkli oklar ise, zorunlu olarak geçilmesi gereken durumları ifade eder.

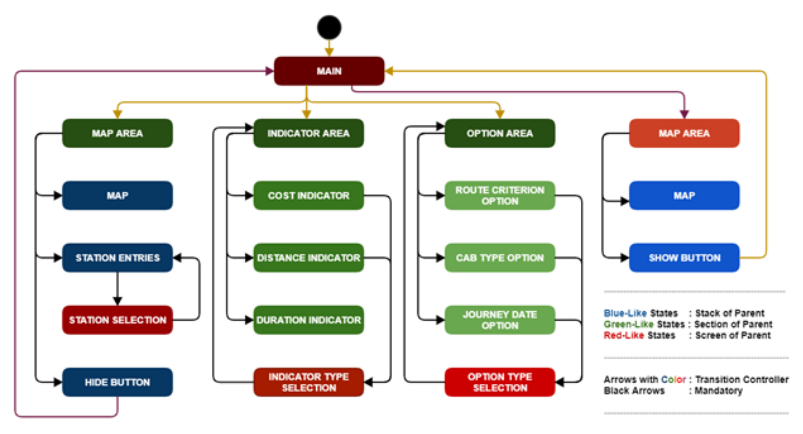

Şekil 14 Kullanıcı Arayüz Tasarımı

Verilen durumlar ve ilişkileri kullanılarak oluşturulan arayüz tasarımı Şekil 15,16,17,18'de gösterilmektedir. İlgili arayüzde, referans alınan iki temel tasarım prensibi bulunmaktadır. Bunlardan ilki, kullanıcının olabildiğince arayüzü tek elle kullanabilmesi ve diğer el kullanımının insiyatife bırakılmasıdır. $\mathrm{Bu}$ amaçla; konum düzenleme (ekleme, silme ve değiştirme), rota hesaplama, yolculuk gösterge tiplerini düzenleme, yolculuk kriterlerini düzenleme görevlerinin gerçekleştirilmesini sağlayacak bileşenler, yaklaşık olarak baş parmak kullanılarak erişilebilecek konumlara yerleştirilmiştir. İkincisi ise, arayüzün kullanıcının istediği tek el ile kullanılabilmesidir. Bu amaçla; arayüz bileşenleri olabildiğince her iki yatay kenara da yakın olabilecek şekilde konumlandırılmaya çalışılmıştır. Bu prensibe aykırı tek bileşen olan rota seçme butonları, sağ kenara dayalıdır. Bunun sebebi, konum girdilerinin harita alanını dikey eksende küçültme potansiyelinin yüksek olabilmesidir. Dolayısıyla dikeyn eksende daha fazla bileşenin yer kaplamasının haritayı görüntüleme ve düzenleme (ölçek büyütme/küçültme, görüntülenen alanın kaydırılması) işlemlerini zorlaştırabileceği düşünülmektedir.

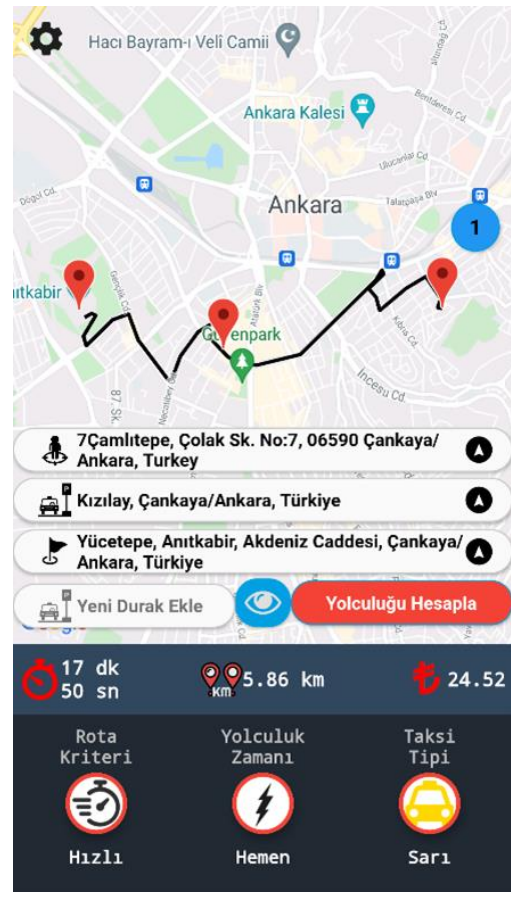

Şekil 153 Konum Girdili Arama Sonucu Ekranı

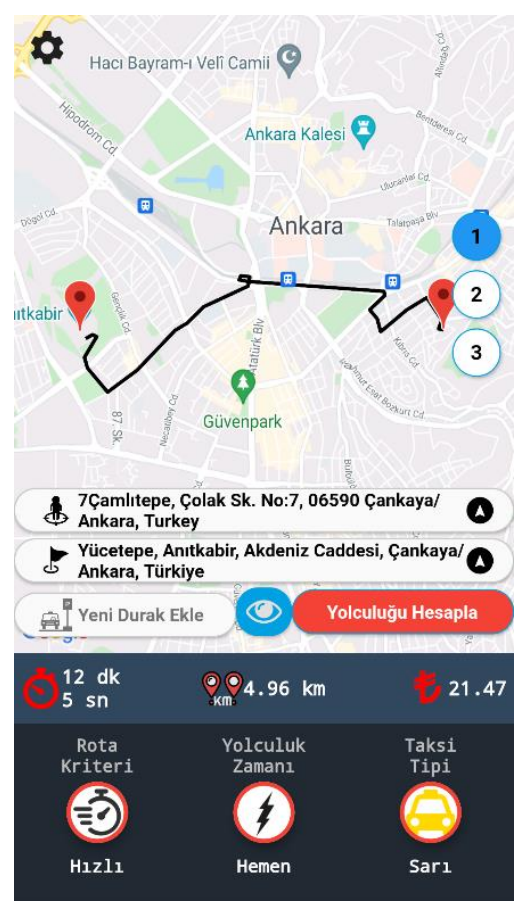

Şekil 162 Konum Girdili Arama Sonucu Ekranı 


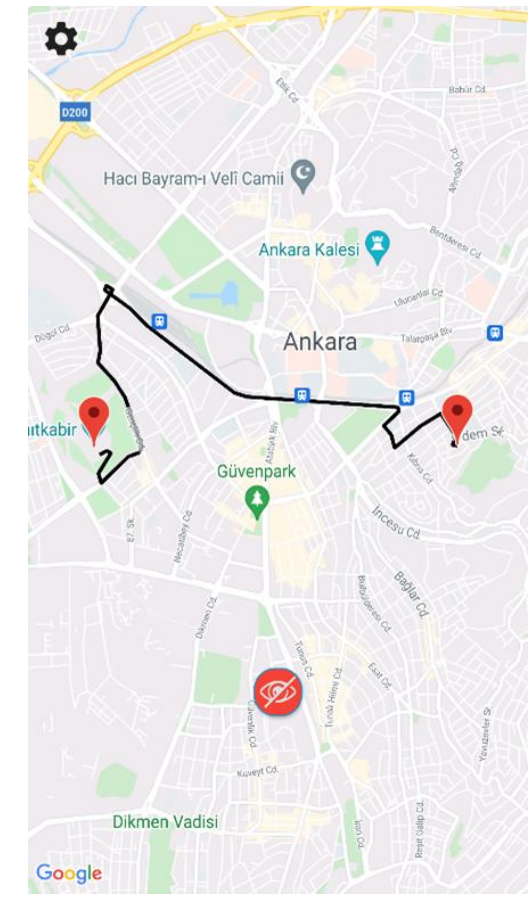

Şekil 17 Haritanın Tam Ekran Olması

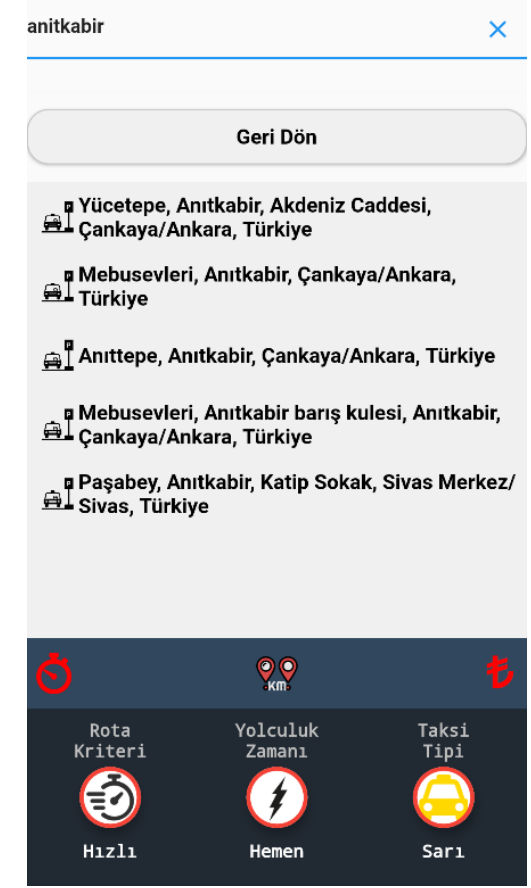

Şekil 18 Konum Arama Ekranı

\subsection{Yolculuk Değişkenleri Algoritmaları}

Taksilerde bulunan taksimetrelerin ücret hesaplayabilmesi için bazı ölçüm bilgilerine ihtiyacı vardır. Bu değişkenler taksi tarifelerinde gösterilir. $\mathrm{Bu}$ tarifeler her ilin belediyesi veya ulaştırma koordinasyon merkezi (UKOME) gibi kuruluşlar tarafından belirlenir.

Kullanılacak tarifenin seçilebilmesi için normal kullanımda olduğu gibi geliştirdiğimiz uygulamanın da bazı bilgilere ihtiyacı vardır. Bu bilgiler aşağıdaki gibi üç adettir.
- Bulunduğu bölgeye özel bir tarifenin olup olmama durumu

- Bulunduğu bölgede gece- gündüz tarife ayrımının yapılıp yapılmadığı

- Yolculuk yapmak için seçilen aracın tipinin ne olduğu (sarı, turkuaz, siyah)

Uygulama açıldığında Google Geocoding Api sayesinde kullanıcıların konumlarına ait ilçe, il ve ülke bilgileri alınmaktadır. Bulunduğu bölgeye özel bir tarife (belirli ilçelerde kullanılan veya sadece belirli bir havaalanında kullanılan bir tarife vb.) yoksa bulunduğu şehrin tarife özelliği seçilir. Bulunduğu bölgeye özel tarife var ise o bölgeye ait tarife özelliği seçilir.

Gece ve gündüz tarifesi için ilk olarak kullanıcının şehir bilgisi alınır. $\mathrm{Bu}$ şehirde gece ve gündüz tarifesi yok ise gece ve gündüz tarifesi bilgilerinin ortak olduğu tarife özelliği seçilir. Gece ve gündüz tarifesi farkının olduğu durumlarda ise zaman bilgisine bakılır. Saat 00.00- 05.59 saatleri arasında ise gece tarifesi, 06.00-23.59 saatleri arasında ise gündüz tarifesi özelliği seçilir. Gece ve gündüz tarifesinin temel farkı fiyatın hesaplanma modelinden değil, fiyat hesaplarken kullanılan değişkenlerin (100 metre başına ücret artışı, açılış ücreti vb.) büyüklüklerinden gelmektedir.

Kullanıcı kullanmak istediği taksi araç tipini seçtikten sonra (sarı, turkuaz, siyah) 3 özelliğin mevcut olduğu tarife bilgisi veritabanından sorgulanır. Kullanıcı başka bir şehir/bölge için arama yapması halinde aynı özellikler (özel bölge, gece- gündüz, taksi tipi) o şehir/bölge için tekrar ayarlanarak veritabanından yeni tarife bilgisi sorgulanarak elde edilir. Uygulamanın konum girdisi veya kullanıcının konumunu alarak elde ettiği şehir ve bölge bilgilerine göre taksi tipleri aktif/pasif duruma geçmektedir.

\subsubsection{Tahmini Bekleme Süresi Hesaplama}

Bekleme süresi, taksi yolculuğunda varış konumuna ulaşıncaya dek taksinin hareketsiz kaldığı sürelerin toplamıdır. Örneğin; yolculukta olan bir taksinin kırmızı 1şıkta veya trafikte hareketsiz kalması, bekleme süresi olarak isimlendirilir. Bekleme süresi yolculuk ücretini artıran bir değişkendir, dolayısıyla çalışmadaki tahmini ücret hesaplamasının doğruluğu için önem arz eder. Genel olarak, bekleme süresi bir rotayı meydana getiren ayaklardaki (bulvar, cadde, vb.), örneğin; hız sınırları, trafik sıkışıklığı ve yol çalışmalara bağlı olarak uzayabilir. Bu nedenle, hesaplanan yolculuk güzergahı ve saatiyle doğrudan ilişkilidir.

Bekleme süresini hesaplarken farklı yaklaşımlar kullanılabilir. Örneğin, GDA kullanılarak bir rota hesaplanır ve içerisinden yolculuk süresi alınır. GDA'dan alınan yolculuk sürelerine bekleme süresi de (kullanıcıların trafik verilerinden oluşturulması nedeniyle) dahildir. Bunun ardından, rotanın her bir ayağın hız sınırları (örneğin; A caddesinde $50 \mathrm{~km} / \mathrm{s}$ ) ve ayaklardaki mesafe değerleri kullanılarak, bekleme süresiz yolculuk süresi hesaplanabilir. Bekleme süreli ve süresiz yolculuk sürelerinin birbirlerinden çıkarılması, bekleme süresini verecektir.

Fakat GDA, bekleme süresiz yolculuk süresi değeri sağlamamaktadır. Ayrıca, Google Web Servisleri veya farklı bir kaynak üzerinden, bir rota ayağı için hız sınırı bilgilerine de erişilememiştir. Dolayısıyla, bekleme süresini bulmak üzere alternatif bir yöntem öneriyoruz. Bu yöntemde, öncelikle yolcunun yolculuk yapmak isteyeceği saate göre rotalar 
hesaplanır. Daha sonra, aynı başlangıç ve varış konumları (varsa durak[-lar] da dahil olmak üzere) için en düşük yolculuk süresini verecek yolculuk saati bulunur. En düşük yolculuk süresinin bulunduğu saati bulabilmek için, bir sonraki günün her saati için (00'dan 23'e kadar) rotalar hesaplanabilir. Yolculuğun yapılacağı saat için hesaplanan rotanın süresinden en düşük yolculuk süresinin çıkarılması, bekleme süresi olarak kabul edilir.

GDA'den alınabilecek 2 tip yolculuk süresi vardır: "duration" ve "duration in traffic". "Duration" değeri, rota üzerindeki geçmiş trafik verileriyle oluşturulmuş yolculuk süresini verir. "Duration in traffic" değeri ise, güncel trafik verileri ve geçmiş trafik verileri kullanılarak oluşturulmuş yolculuk süresidir. Önemli bir not olarak, ilgili değerler saat bazında verilmektedir. Buna göre; saat 14:00 ile 14:59 aynı değerleri verirken saat 15:00 için farklı değer verir. Bu iki değişkeni karşılaştırmak amacıyla deney niteliğinde sorgular tasarlanmış ve Google Directions hizmetine gönderilerek her iki değişkenin değişim trendi incelenmiştir. Deneyde, İstanbul Fatih'den İstanbul Taksim'e rotalar hesaplanmıştır. Rota hesaplaması, 2021 yılının her saatini kapsayacak şekilde 1 yıllıktır (360 gün). Böylece, bir y1l içinde farklı yolculuk tarih ve saatlerindeki yolculuk süreleri bu iki değişkene bağlı olarak (Duration ve Duration in Traffic değişkenleri) elde edilmiştir.

Şekil 19'daki Grafikte 360 adet “duration” (kırmızı) ve 360 adet "duration in traffic" (mavi) eğrisi bulunmaktadır. Genel olarak, "duration" değerinin neredeyse doğrusal, "duration in traffic" değerinin ise saatlere göre değiştiği görülebilir. Trafik yoğunluğu gibi dinamik olayların yolculuk süresini değiştirme potansiyeli nedeniyle, önerdiğimiz alternatif bekleme süresi hesaplama yaklaşımında "yolculuk süresi” değişkeninin karşılığı olarak "duration in traffic" değerini alıyoruz. Ayrıca en düşük yolculuk süresine sahip yolculuk saatinin belirlenmesine yönelik bir çıkarım yapılabilir. İlgili çıkarım, yolculuk sürelerinin gece saatlerinde (yaklaşık olarak 01:00 ve 06:00 aralığ 1 ), diğer saatlerle kıyasla daha düşük olmasıdır.

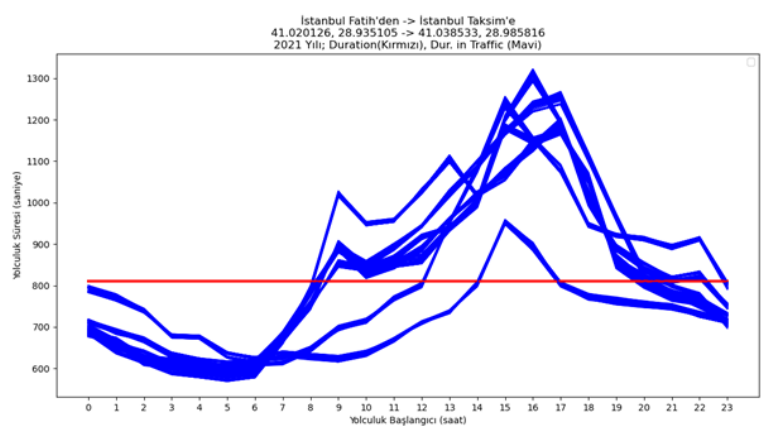

Şekil 19 Duration ve Duration in Traffic Değeri (İstanbul FatihIstanbul Taksim) (00.00-23.59)

Şekil 20'de yapılan deneyin 00:00-06:00 aralığında yakınlaştırılmış görünümü bulunmaktadır. Şekilde, gece saatlerinde hesaplanmış değerler daha açık görülebilir.

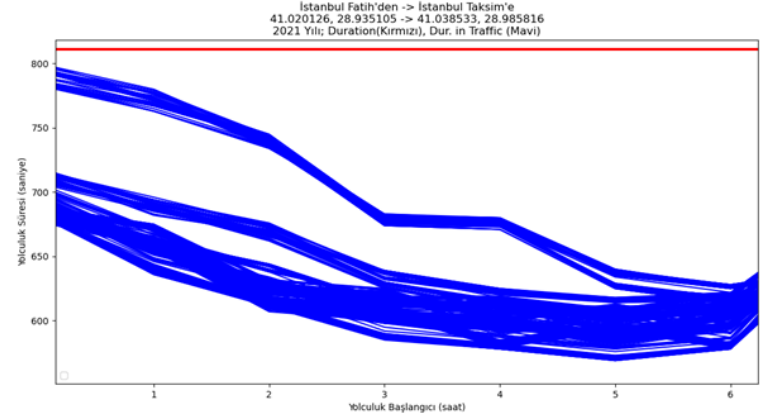

Şekil 20 Duration ve Duration in Traffic Değeri (İstanbul FatihÍstanbul Taksim) (00.00-06.00)

Gece saatlerinde yolculuk süresinin daha düşük çıkması ile ilgili çıkarımı kuvvetlendirmek için farklı konumlar arasında deneyler gerçekleştirilmiştir. İlgili deney sonuçları bir haftalık periyotta yapılmıştır ve Şekil 21,22,23'te sunulmuştur. Eğrilerin kırmızı tonlar1 "duration", mavi tonları "duration in traffic" ve yeşil renklisi ise farklı günlerin aynı saatleri için "duration in traffic" değerlerinin ortalamasını ifade eder.

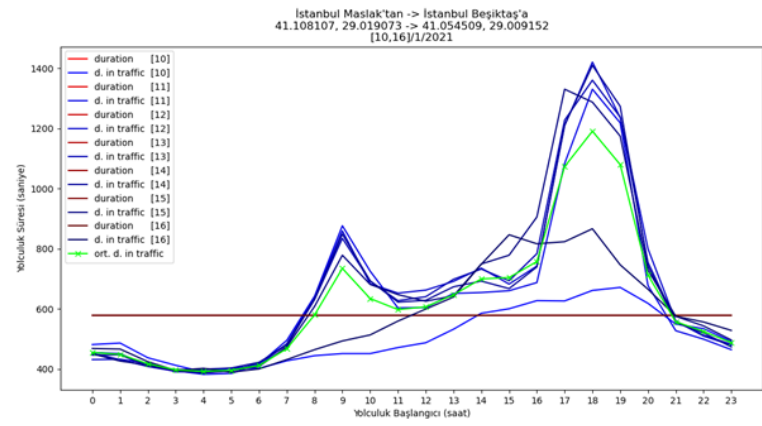

Şekil 21 Haftalık GDA Yolculuk Sürelerinin Klyaslanması \#1

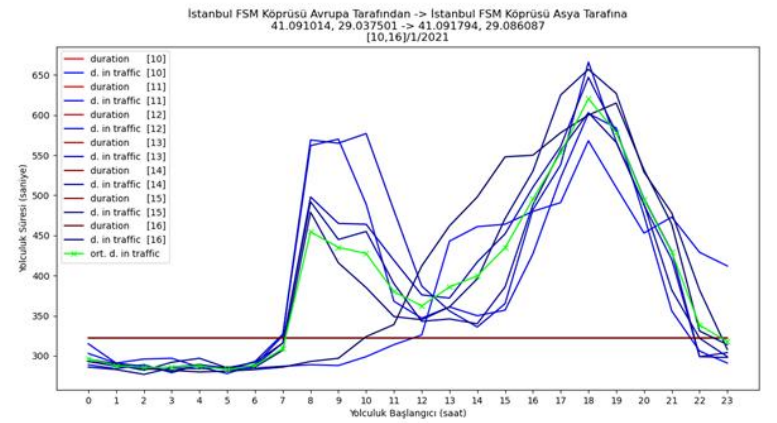

Şekil 22 Haftalık GDA Yolculuk Sürelerinin Klyaslanması \#2

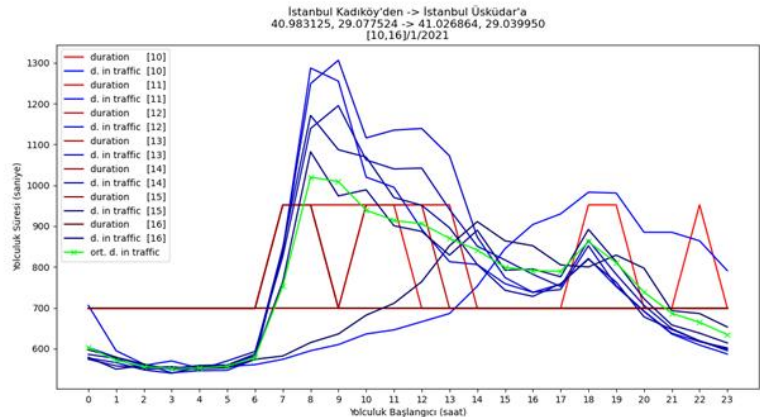

Şekil 23 Haftalık GDA Yolculuk Sürelerinin Kıyaslanması \#3 
İlgili deney sorguları dikkate alındığında, gece saat 04:00 için hesaplanacak bir rotanın daha düşük yolculuk süresi üretebileceği söylenebilir. Yolculuk saati olarak sadece saat 04:00 için yapılacak bir hesaplama, tüm gün veya gece saatleri referans alınarak yapılacak bir hesaplamaya göre GDA'ya gönderilecek istek sayısını azaltabilir. Fakat bu, hesaplama maliyetini iyileştirebileceği gibi, en düşük yolculuk süresini verebilecek rotanın hesaplanmasını engelleyebilir. Örneğin; Şekil 22'de 04:00 için 580 saniye hesaplanan yolculuk süresinin, 05:00 için 570 saniye çıkması gibi. Burada, en düşük yolculuk süresinden uzaklaşılmasıyla birlikte hesaplamanın doğruluğu etkilenecek ve bir hata miktarı ortaya çıkacaktır. İlgili hata miktarının, yolculuk ücretinin hesaplanma süreci üzerinde küçük bir etkisi olabileceği düşünülebilir. Diğer taraftan, sistemin yolcu için sunduğu karardestek mekanizma işlevselliği bu etkiye rağmen korunabileceği söylenebilir.

Bekleme süresini hesaplamak için sabit bir şekilde 04:00 saati seçildikten sonra, modelin doğruluğunu ve maliyetini olumsuz etkileyecek durumlara odaklandığımızda:

1- Yolculuk süresinin 1 saatten uzun sürmesi: Örneğin hesaplanan bir rotanın yolculuk süresi 5 saat olsun. Bu durumda, bekleme süresini hesaplamak için yaklaşık olarak 04:00-09:00 saat aralığındaki yolculuk hesaplanır. Fakat, yolculuk süresinin 04:00'den uzaklaştıkça büyümesi nedeniyle, bekleme süresiz yolculuk süresini hesaplamak için mümkün olduğu kadarıyla yolculuğun başlangıç ve bitiş saatlerinin 04:00' e yakın olması önemli bir ayrıntıdır. Bu durumun önüne geçmek için, rotayı 1'er saatlik parçalara bölüyoruz ve her parçayı saat 04:00'e göre yeniden hesaplatıyoruz. Böylece her 1'er saatlik parça saat 04:00'de başlayıp 05:00 bitecek şekilde yeniden hesaplanır.

2- Rotanın saatlik dilimlere bölünmesinin ardından, her bir alternatif rota için hesaplama maliyetinin artması: Örneğin, yolculuk süresi 5 saat ve toplam 3 alternatif rota hesaplansın. Her bir rotanın birer saatlik dilimlere ayrılması, toplamda 15 hesaplama yapılmasını gerektirir. Bu maliyeti düşürmek için, gece saatlerinde bir zaman aralığı oluşturularak, rotaların 1 saatin üzerindeki dilimlere ayrılması sağlanabilir. Tablo 2'de ilgili optimizasyon için belirlenen yöntemin sözde kodu yer alır. Statik olarak 04:00 saatinin ve saatlik dilim olarak 4'ün seçilmesinin ardından; 5 saat süren rota 4 saatlik parçalara (1 adet 4 saatlik ve 1 adet 1 saatlik) ayrılır. Tüm 4 saatlik tam parçalar, 04:00- (4/2) olarak 02:00'de başlar. Dolayısıyla, en az yolculuk süresine sahip saat 04:00'ün merkezde ve gece saatlerini kapsayan bir hesaplama gerçekleşir. 4 saatten düşük olan parçalar ise verilen örnekte 1 saattir. Geri kalan 1 saatteki rotalar1, 04:00- (1/2) olarak 04:00'de başlatılabilir. Böylece, 5 'er saatlik 3 alternatif rota için toplamda 6 hesaplama yapilır.

Tablo 2. Gece Saatinde Hesaplama Yapılmasına Yönelik Aralık Belirleme

\footnotetext{
statik gece saati $=04: 00$;

tavan aralık saati $=4$;

IF yolculuk süresi >= tavan aralık saati:

statik gece saati $=$ statik gece saati - tavan aralık saati $/ 2$;

ELSE:

statik gece saati $=$ statik gece saati - yolculuk süresi / 2 ;
}

3- Gece saatlerinde (örneğin referans alınan saat 04:00) hesaplanan yolculuk süresinin belirli bir miktar bekleme süresi içerme olasılığı: Bu miktarın, nispeten küçük bir etkiye sahip olabileceğini düşünsekte; hesaplanacak yolculuk ücretinin güvenilirliğini düşük bir oranla olumsuz etkileyeceği açıktır.

4- Yolculuk süresini artırma potansiyeli öngörülemeyecek durumlardan kaynaklı bekleme süresi: Örneğin, yolcu ATM'den para çekmek için taksiyi bir süreliğine durdurabilir veya seyir halindeyken bir kaza gerçekleşmesi sonucunda, beklenmeyen bir şekilde trafik yoğunluğunda artış gözlemlenebilir. Gerçekleşme olasılığının ve etki miktarının, çalışmadaki model doğrultusunda önceden tahmin edilemeyecek olması nedeniyle, bu tip durumlar hesaplamaya dahil edilememektedir.

5-Sistemin bekleme süresi hesaplama yaklaşımından kaynaklanabilecek sorunlar için hata toleransına yönelik önlemlerin alınması: GDA, aynı konumların farklı yolculuk saatlerindeki sorguları için aynı rotaları hesaplama garantisi vermez. Dolayısıyla, istenen yolculuk saati ve sistemin belirlediği gece saati için hesaplanacak rotaların farklı yolları (güzergahları) kullanma ihtimalleri bulunmaktadır. GDA'nın saat farklılığına göre farklı rotalar hesaplama frekansı düşük, fakat bu durumun oluşması halinde tasarlanan sistemin beklenildiği gibi çalışmayacağı da açıktır. Bu nedenle, 2 farklı zaman diliminde hesaplanan rotayı aynılaştırabilmek üzere, gece saatinde hesaplanan rotada düzenleme yapıyoruz. $\mathrm{Bu}$ düzenlemede ikili arama yöntemi kullanılarak, gece ve yolculuk rotalarının benzer olmayan parçaları tespit edilebilmektedir. Benzer olmayan gece rota parçası, yolculuk rotasındaki başlangıç ve varış konumuna göre yeniden hesaplatılır ve bu işlem, gece rotası ile yolculuk rotasının aynı olmasıyla sonlanır. Tablo 3'teki sözde kod, ilgili yöntemin algoritmasını göstermektedir. Algoritmada "rota" tipinde olan değişkenler hesaplanan rotaya işaret etmekte ve bir dizi şeklinde çalışarak her bir indeksi sıralı olarak gidilecek konum bilgisini vermektedir. Kısaca, gece saatinde hesaplanan rota ile yolculuk saatinde hesaplanan rota ikişer eş parçaya ayrılarak "ilk" ve "son" şeklinde parçalar (GeceRotasililk GeceRotasıSon YolculukRotasillk ve YolculukRotasıSon) elde edilir. Elde edilen "ilk" ve "son" kategorisindeki parçalar birbirleri ile kıyaslanarak, gece ve yolculuk saati rotalarının aynı olmadığı kategorideki parçalar (sadece gece saati için) yeniden iki eş parçaya, dolayısıyla da kategoriye (ilk ve son) ayrılır.

Ayrica 5. probleme ek olarak; GDA farklı saat dilimlerinde yapılan sorgular için farklı sayılarda rota hesaplayabilir.

Dolayısıyla, gece saati için hesaplanan rota sayısıyla yolculuk saatinde hesaplanan rota sayıları aynı olmayabilir (Örneğin; yolculuk saatinde 3 rota ve gece saatinde 1 rota). Bekleme süresinin her bir rotada doğru şekilde hesaplanması, yolculuk saatinde hesaplanan her rotanın gece saati için de hesaplanmasını gerektirir. Tablo 3 'te verilen yöntem kullanılarak, rota sayıları aynı olmasa dahi, yolculuk saatinde hesaplanmış bir rota gece saati için de hesaplanabilir. Fakat burada, gece saatinde hesaplanan herhangi bir rotanın bekleme süresiz olduğunu kabul etmemiz nedeniyle, rota hesaplama maliyetini azaltmaya yönelik ek bir işlem adımı ekliyoruz. Bu işlemde, gece ve yolculuk saati için hesaplanan rotalardan 1 tanesinin aynı olması gerekmektedir (Eğer değilse Tablo 3'teki yöntem 1 kez uygulanır). Yolculuk saatindeki aynı rotanın mesafesi ve aynı olmayan rotanın mesafesinin oranı, aynı olan rotalar arasındaki bekleme süresiyle doğru orantılı olarak kabul edilir. 
Örneğin bir yolculuk saati için A konumundan B konumuna $\mathrm{X} 1, \mathrm{X} 2, \mathrm{X} 3$ ve gece saati için sadece $\mathrm{X} 1$ rotası hesaplanmış olsun. Yolculuk saati için hesaplanan X1 rotasının yolculuk süresinden, gece saati için hesaplanan $\mathrm{X} 1$ rotasının yolculuk süresinin çıkarılması, X1 rotası için bekleme süresini verir. Bu doğrultuda, gece saatinde karşıllı̆ 1 bulunmayan X2 (veya X3) rotasının bekleme süresini hesaplamak için aşağıdaki işlem yapılır:

X2 Bekleme Süresi $=(X 1$ Bekleme Süresi $*$ X2 Mesafesi $) /$ X1 Mesafesi

\subsubsection{Her Rota İçin Tahmini Ücret Hesaplama}

Taksiler yolculuklarında fiyat ölçmek için taksimetre adı verilen cihazları kullanırlar. Bu cihazlar mesafeyi ve zamanı ölçerler. Mesafe bilgisi mesafeye bağlı olan ücret hesaplamasında kullanılırken, zaman bilgisi bekleme süresine bağlı olan ücret hesaplamasında kullanılır. Bu hesaplanan fiyat bilgisi bölgeden bölgeye veya şehirden şehire farkll11k göstermektedir. Bu farklılık taksimetrede kullanılan geçerli tarifeden dolayı oluşmaktadır.

\section{Tablo 3. Gece Rotasını Aynılaştır Algoritması}

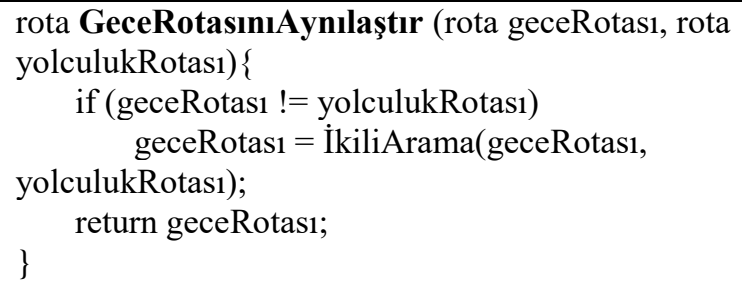

rota İkiliAramaEşitlikKontrolü (rota geceRotas1, rota yolculukRotasi) \{

if (geceRotas1 != yolculukRotas1) \{ yeniRota $=$ GDApiSorgu (yolculukRotası[0].konum,

olculukRotasi.length].konum); yolculukRotasi[y yolculukRotas1); return İkiliArama(yeniRota,

\}

return geceRotasi;

\}

rota[] RotayıİkiyeBöl (rota_rota):

ilkRota =_rota[0 :_rota.length $/ 2]$;

sonRota =_rota[_rota.length $/ 2$ :_rota.length]; return ilkRota, sonRota;
Örneğin, bir taksimetre 91,4 metrede bir ücret ekliyorsa ancak taksimetreye sinyaller her bir yarda bir yani 0,9 metrede bir geliyorsa; taksimetre 100 tane sinyale ulaştığı zaman ücreti ekrana yansitmaktadır. Taksimetre ücretlendirmesi konusunda, New York City'den bir örnek verilecek olursa; taksimetrenin açılışı 2,5 dolardır. Seyahat edilen her 300 metrede bir ödenecek olan ücrete 40 cent eklenmektedir. Buna ek olarak otomobilin hareket etmediği her dakikada 40 cent ücrete eklenmektedir [24].

$\mathrm{Bu}$ ölçüm değerleri başka bir şehirde mesafeye bağlı olan ücret için her 100 metrede bir $0.35 \mathrm{TL}$, bekleme süresine bağlı olan ücret için her 60 saniyede bir $0.48 \mathrm{TL}$ artış olarak gözlemlenebilir.

$\mathrm{Bu}$ çalışmada da yukarıdaki bilgilerden yararlanılarak aşağıda belirtilen taksimetrelerin fiyat hesaplamak için kullandığı algoritma kullanılmıştır.

- Taksimetre aracın ilerlediği her 100 metrede bir $\mathrm{X}$ birim ücret yazar.

- Taksimetre ilk 5 dakika için bekleme ücreti yazmaz.

- 5 dakikalık bekleme süresinin sonrasında her 30 saniyede bir $\mathrm{Y}$ birim ücret yazar

- Hız eşiğinin $(10-15 \mathrm{Km} / \mathrm{Saat})$ altında bir hızla ilerliyorsanız taksimetre otomatik olarak bekleme konumuna geçer ve zaman sayma işlemlerine başlar [25].

$\mathrm{X}, \mathrm{Y}$ birimleri yetkili kurumların belirlediği tarifeler için farklılık gösterebilir.

Son olarak hesaplanan bu tahmini ücret ile tarifede geçerli olan yolculuk başına minimum ücret karşılaştırılır. $\mathrm{Bu}$ karşılaştırmada daha büyük olan ücret yolculuğun tahmini ücreti olarak seçilir. Bu hesaplamalar her rota için yapılmaktadır.

\section{Sonuç ve Tartışma}

$\mathrm{Bu}$ çalışmada, taksi yolculuk sürecinin bir parçası olan Yolculuk Tasarlama aşaması için yeni bir model tasarlanmış ve bir mobil uygulama yazılımı olarak gerçekleștirilmiş̧ir. Modelin tek aktörü olan yolcu, uygulamayı kullanarak rota hesaplayabilir ve rotası için yolculuk değişkenlerini görüntüleyebilir.

Yolculuk beklentileri ve sonuçları arasındaki farklılığın neden olduğu yolculuk sorunları, beklenti ve gerçek arasındaki farkın azaltılmasıyla veya kaldırılmasıyla önlenebilir. Bu sonucun kazanılması için uygulama, bazı hesaplama algoritmalarıyla donatılmıştır. Hesaplama algoritmaları rotaları kategorize (önerilen ve alternatifleri) edebilir ve yolculuk değişkenlerini (tahmini süre, mesafe ve ücret) oluşturabilir.

Çalıșmanın bir diğer katkısı ise bekleme süresini hesaplamaya yönelik uyguladığı yaklaşımdır. Hesaplanan bekleme süresi, tahmini yolculuk ücretini hesaplamak için GDA'dan alınan bilgiler içerisinde, yolculuk ücretinin doğruluğunu en fazla etkileyebilecek değerdir.

Uygulamadaki ücret hesaplama yaklaşımı taksimetredeki hesaplama yöntemini referans alır. Dolayısıyla yaklaşık ücretlendirme sonuçlarını oluşturabilir. Fakat yolculukta ek ücret gerektiren durumlarla karşılaşılabilir. Örneğin hesaplanan rota içerisinde ücretli bir güzergah (örneğin köprü, otoban vb.) bulunabilir. Uygulamada ücretli yollar ve taksimetreye yansıma 
tutarları tanımlanmamıştır. $\mathrm{Bu}$ nedenle, uygulamanın ücretli güzergahlar için hesapladığı tahmini ücret ve gerçek ücret arasında anlamlı bir fark bulunabilir. Ücret hesaplama yaklaşımının, ücretli güzergahlar için de gerçeğe yakın değerler üretebilmesi için ilgili tanımlamaların yapılması gerekir.

Uygulama rota hesaplamak için GDA'yi kullanır. GDA'dan alınan rotalarda düzenleme yapılmaz ve uygulama tarafindan doğrudan kullanılır. Dolayısıyla rotalar hesaplanırken kullanıcının isteyebileceği bazı hesaplama şartları belirlenemez. Örneğin; hesaplanan rotalar ücretli bir güzergahı kullanıyor, dolayısıyla da yolculuk ücretini istenmeyecek miktarda artıyor olabilir. Bu noktada kullanıcı, sadece ücretsiz güzergahlardan geçen bir rota hesaplanmasını isteyebilir. Uygulamada bu isteği gerçekleştirebilecek bir yöntem bulunmamaktadır. Fakat kullanıcı kendi sezgiselliğine başvurarak, ücretli yollardan geçilmemesi için, ara durak ekleme imkanını değerlendirebilir. Örneğin ücretsiz bir yolun (ücretli yolun alternatifi olan) başlangıcına ve sonuna ekleyeceği durak konumlarıyla, hesaplanan rotanın ücretsiz yolu kullanması sağlanabilir.

Yolculuk sürecinde karşılaşılan sorunların ve kullanılabilirlik eksikliklerinin her birine yönelik çözüm üretebilecek bir sistem, yolculuk aşamalarının her biri için kapsamlı işlev ve işlem kümelerine sahip olmalıdır. Bu çalışmadaki model sadece ilk aşama içerisinde karşılaşılabilecek sorunlara yönelik çalışmakta ve dolayısıyla da yolculuk sürecini bütüncül bir yaklaşımla ele almamaktadir.

\section{Kaynakça}

[1] İstanbul Toplu Taşıma Araçları verileri. (2021, Ocak 8). Taşımacılar.com:

https://www.tasimacilar.com/yerel/istanbul-toplu-tasimaaraclari-verileri-20725h adresinden alınd

[2] Istanbul'da Toplu Taşıma Istatiskileri. (2021, Ocak 8). İETT: https://www.iett.istanbul/tr/main/pages/istanbulda-topluulasim/95 adresinden alınd 1

[3] Istanbul Nüfusu. (2021, Ocak 8). Nufusu.com: https://www.nufusu.com/il/istanbul-nufusu adresinden alınd1

[4] Beyaz Masa Taksi Şikayetleri. (2021, Ocak 8). NTV: https://www.ntv.com.tr/turkiye/beyaz-masaya-gunde-490taksi-sikayeti-geliyor-yolcu-secme-ters-cevap-vermebo,cjuct8Dj70C5OhmduujKWQ adresinden alındı

[5] Y.K. Yuce, A. Coban, S. Inanir, Y. Isler, Process Models in Mobile Applications Developed for Cab Journey: Deficiencies in Passenger Control and a New Model Suggestion (Taksi Yolculuğu Iç̧in Geliştirilmiş Mobil Uygulamalarda Süreç Modelleri: Yolcu Hakimiyeti Açısından Eksikler ve Yeni Bir Model Önerisi), Avrupa Bilim ve Teknoloji Dergisi (European Journal of Science and Technology), IN PRESS, 2021.

[6] Google Play Arama 1. (2021, Ocak 8). Google Play: https://play.google.com/store/search?q=Taxi\%20Fare $\% 2$ BTa $\mathrm{xi} \% 20$ Calculator-game $\& \mathrm{c}=$ apps adresinden alınd 1

[7] Google Play Arama 2. (2021, Ocak 8). Google Play: https://play.google.com/store/search?q=Taksi\%20Fiyat $\% 20$ Hesaplama $\% 2$ C\%20Taksimetre\%20Fiyat $\% 20$ Hesaplama $\% 2$ 0 -game \&c $=$ apps adresinden alınd 1

[8] Taxi- Calculator. (2021, Ocak 8). Google Play: https://play.google.com/store/apps/details?id=de.taxirechner adresinden alındı
[9] Taxi Fare. (2021, Ocak 8). Google Play: https://play.google.com/store/apps/details?id=com.taxifare adresinden alind 1

[10] Taxi Fare Calculator. (2021, Ocak 8). Google Play: https://play.google.com/store/apps/details?id=taxifare.japant axi.co.jp adresinden alınd 1

[11] Thai-Taxi Fare Calculator. (2021, Ocak 8). Google Play: https://play.google.com/store/apps/details?id=com.bangkokh asyou.thaitaxicalculator adresinden alind 1

[12] istTaksi - Taksimetre. (2021, Ocak 8). Google Play: https://play.google.com/store/apps/details?id=com.tildadev.t aksimetre adresinden alınd 1

[13] Traffic Layer. (2021, Ocak 8). Google Maps Platform: https://developers.google.com/maps/documentation/javascri $\mathrm{pt} /$ examples/layer-traffic adresinden alınd 1

[14] Google Maps Help. (2021, Ocak 8). Google Maps Help: https://support.google.com/maps/answer/3092439?hl=en\&vi sit_id=637431440426607777-3822680287\&rd=1 adresinden alındı

[15] Liu, K., Chen, S. S., \& Smith, M. J. (2009). U.S. Patent No. $12 / 272,466$.

https://patents.google.com/patent/US20090287405A1/en adresinden alınd 1

[16] Pokorný, P. (2017, August). Determining Traffic Levels in Cities Using Google Maps. In 2017 Fourth International Conference on Mathematics and Computers in Sciences and in Industry (MCSI), (s. 144-147).

[17] In Google Maps, what do the different colors like orange, red, and blue signify in a particular recommended route? (2021, Ocak 8). Quora: https://www.quora.com/In-GoogleMaps-what-do-the-different-colors-like-orange-red-andblue-signify-in-a-particular-recommended-route adresinden alındı

[18] Fan, R. C., Yang, X., \& Fay, J. D. (2003). U.S Patent No. $6,594,576$. https://patents.google.com/patent/US6594576B2/en adresinden alınd 1

[19] Joseph, J. (2007). U.S. Patent No. 7,197,320. https://patents.google.com/patent/US7197320B2/en adresinden alınd 1

[20] Jain, R., Goel, S., \& Neverov , G. (2014). U.S. Patent No. $8,880,323$.

https://patents.google.com/patent/US20100286899A1/en?oq $=+$ Google + Patent + Application + US $+2010 \% 2 f 0286899+\mathrm{A} 1$ adresinden alınd 1

[21] How Does Google Maps Predict Traffic. (2021, Ocak 8). howstuffworks: https://electronics.howstuffworks.com/howdoes-google-maps-predict-traffic.htm adresinden alındı

[22] Rezzouqi, H., Gryech, I., Sbihi, N., Ghogho, M., \& Benbrahim , H. (2018, September). Analyzing the Accuracy of Historical Average for Urban Traffic Forecasting Using Google Maps. In Proceedings of SAI Intelligent Systems Conference (s. 1145-1156). Springer, Cham.

[23] Structured analysis and design technique. (2021, Temmuz 5). wikipedia.org:

https://en.wikipedia.org/wiki/Structured_analysis_and_desig $\mathrm{n} \_$technique adresinden alınd 1

[24] Taksimetre Nasıl Çalışır? (2021, Ocak 8). Otorapor: https://otorapor.com/taksimetre-nasilcalisir\#: :text=Taksimetreler\%20genel $\% 20$ hatlarıyla $\% 20 \mathrm{za}$ man $\% 2$ Fmesafe,ya $\% 20$ da $\% 20$ daha $\% 20$ fazla $\% 20$ ödeyebilirs iniz adresinden alınd 
[25] Teknik Dosyalar. (2021, Ocak 8). Tetaş Elektronik: http://www.tetaselectronic.com/Images/Uploads/Files/24030 90602_1453_TEKN_K_DOSYA_STANDARTLAR_VE.D OC adresinden alınd 1

[26] Osswald, S., Brueckel, N., Brickwedde, C., Lienkamp, M., \& Schoell, M. (2014, September). Taxi Checker: A Mobile Application for Real-Time Taxi Fare Analysis. In Adjunct Proceedings of the 6th International Conference on Automotive User Interfaces and Interactive Vehicular Applications (pp. 1-6).

[27] Noulas, A., Salnikov, V., Hristova, D., Mascolo, C., \& Lambiotte, R. (2018, October). Developing and deploying a taxi price comparison mobile app in the wild: Insights and challenges. In 2018 IEEE 5th International Conference on Data Science and Advanced Analytics (DSAA) (pp. 424-433). IEEE.

[28] Li, Y., Xia, T., \& Duan, H. (2014). The impact on taxi industry of taxi-calling mobile apps in shanghai (No. 143867).

[29] Akbulaev, N. (2020). The impact of the taxi service mobile applications on the financial condition of taxi companies. International Journal of Scientific and Technology Research, 9(2), 2144-2150.

[30] Google Maps API. (2021, Kasim 24). Google Maps Platform: https://developers.google.com/maps adresinden alınd 1

[31] Google Geocoding API. (2021, Kasim 24). Google Maps Platform:

https://developers.google.com/maps/documentation/geocodi ng/overview adresinden alınd 1

[32] Google Directions API. (2021, Kasım 24). Google Maps Platform:

https://developers.google.com/maps/documentation/directio ns/overview adresinden alınd 1

[33] Google Places API. (2021, Kasım 24). Google Maps Platform:

https://developers.google.com/maps/documentation/places/ web-service/overview adresinden alınd 1

[34] Google Places Autocomplete API. (2021, Kasim 24). Google Maps Platform: https://developers.google.com/maps/documentation/javascri $\mathrm{pt} / \mathrm{places}$-autocomplete adresinden alınd 1

[35] SQLite. (2021, Kasım 24). Sqlite: https://www.sqlite.org/index.html adresinden alındı

[36] Sajid, A., Ayid, A. M., Majed, A. D., \& Faisal, A. M. (2018). Taxi services in saudi arabia through mobile apps: An empirical investigation. Research Journal of Finance an $d$ Accounting, 9, 95-104. 